\title{
Ortaokul Öğrencilerinin Modelleme Becerilerinin Belirlenmesi ${ }^{1}$
}

Hakan Şevki Ayvacı

\section{Sinan Bülbül ${ }^{3}$}

\section{Type/Tür:}

Research/Araştırma

Received/Geliş Tarihi: June 24/

24 Haziran 2019

Accepted/Kabul Tarihi:

November 27/ 27 Kasim 2020

Page numbers/Sayfa No: 1000 -

1028

Corresponding

Author/Illetişimden Sorumlu

Yazar: hsayvaci@gmail.com

\section{$\checkmark$ iThenticate}

This paper was checked for plagiarism using iThenticate during the preview process and before publication. / Bu çalışma ön inceleme sürecinde ve yayımlanmadan önce iThenticate yazılımı ile taranmıştır.

Copyright (C) 2017 by

Cumhuriyet University, Faculty of Education. All rights reserved.

\section{Öz}

Fen bilimleri, doğası gereği pek çok soyut ya da anlaşılması zor kavrama sahip bir bilim dalıdır. Bu soyut ve anlaşılması zor kavramları somutlaştırmanın ve daha anlaşılır bir hale getirmenin yöntemlerinden biri de derslerde modelleme çalışmalarına yer verilmesidir. Fakat modelleme süreci sanıldığı kadar kolay olmayıp, uzun soluklu çalışmalar gerektiren bir süreçtir. Bu, modelleme süreçlerinde öğrencilerin sahip olmaları gereken becerilerin neler olduğunun bilinmesinin, oluşturulacak modellerin ve bunlarla gerçekleştirilecek öğretimin etkili olmasını sağlayacağı düşünülmektedir. Bu doğrultuda araștırmanın amacı, ortaokul öğrencilerinin modelleme sürecinde ihtiyaç duydukları becerilerin belirlenmesidir. Araştırmaya Seçmeli Bilim Uygulamaları dersini alan 17 beşinci sınıf, 22 altıncı sınıf ve 18 yedinci sınıf olmak üzere toplam 57 öğrenci katılmıştır. Araştırma, nitel araştırma yöntemlerinden özel durum çalışması yöntemi ile yürütülmüş olup, veriler mülakatlar ve araştırmacı alan notları ile toplanmıştır. Toplanan veriler içerik analizine tabi tutulmuş, elde edilen veriler tümevarımsal bir şekilde sunulmuştur. Araştırmada modelleme için zihinsel beceriler başlığı altında uzamsal beceriler (uzamsal görselleştirme, uzamsal algılama, uzamsal rotasyon), orijinal fikir üretme, analojik akıl yürütme ve yapısal ilişki eşleştirme; modelleme için süreçsel beceriler başlığı altında malzeme-araç ilişkisi kurma, malzeme-model ilişkisi kurma, modele ilişkin araştırma yapma ve model planı hazırlama olmak üzere toplam sekiz beceri belirlenmiştir. Bu beceriler, öğrencilerin modelleme süreçlerinde daha kaliteli ürünler elde etmelerini sağlaması açısından oldukça önemli olabilir. Çünkü yaparak yaşayarak öğrenilen bilgilerin pekiştirilmesi, soyut kavramların somutlaştırılması açısından öğrencilerin model üretim süreçlerindeki becerilerinin yüksek olması, fen bilimlerini öğrenmelerini de doğrudan etkileyecektir.

Anahtar Kelimeler: Fen eğitimi, model, modelleme, modelleme becerileri, ortaokul öğrencileri.

\section{Suggested APA Citation/Önerilen APA Atıf Biçimi:}

Ayvacı, H. S.., \& Bülbül, S. (2020). Identification of modeling skills of secondary school students. Cumhuriyet International Journal of Education, 9(4), 1000-1028. http://dx.doi.org/10.30703/cije.581752

\footnotetext{
${ }^{1} \mathrm{Bu}$ çalışma, ikinci yazarın "Ortaokul Öğrencilerinin Modelleme Becerilerinin Belirlenmesi, Bu Becerilere Yönelik Bilgisayar Tabanlı Etkinliklerin Geliştirilmesi, Uygulanması ve Değerlendirilmesi” başlıklı doktora tezinden üretilmiştir.

2 Prof. Dr., Trabzon Üniversitesi, Fatih Eğitim Fakültesi, Trabzon/Türkiye Prof. Dr., Trabzon University, Fatih Faculty of Education, Trabzon/Turkey e-mail: hsayvaci@gmail.com ORCID ID: orcid.org/0000-0002-3181-3923

${ }^{3}$ Dr., Trabzon Üniversitesi, Fatih Eğitim Fakültesi, Trabzon/Türkiye Dr., Trabzon University, Fatih Faculty of Education, Trabzon/Turkey e-mail: sinanbulbul@gmail.com ORCID ID: orcid.org/0000-0003-1974-781X
} 


\title{
Identifying Modeling Skills of Secondary School Students
}

\begin{abstract}
Science is, by nature a branch with many abstract or difficult to understand concepts. One of the methods of embodying these abstract and hard to understand concepts and making them more understandable is to include modeling activities in the courses. However, the modeling process is not as easy as it is thought, and it is a process that requires long term studies. It is thought that knowing the skills that students should have in these modeling processes will enable the models to be created and the teaching to be performed with them to be effective. Accordingly, the aim of the study is to determine the skills that middle school students need in the modeling process. A total of 57 students from the Elective Science Applications course, including 17 fifth grade, 22 sixth grade and 18 seventh grade, participated in the study. The research was conducted with the case study method, which is one of the qualitative research methods, and the data were collected through interviews and researcher field notes. The collected data were subjected to content analysis and the data obtained were presented inductively. In the research, eight skills were identified, under the title of mental skills for modeling; spatial skills (spatial visualization, spatial perception, spatial rotation), producing an original idea, analogical reasoning and matching structural relationship; under the title of process skills for modeling; building material-tool relationship, building material-model relationship, research on modeling and preparing a model plan. These skills can be very important in terms of providing students with better quality products in modeling processes. Because the students' skills in the model production process will be directly affected in terms of reinforcing the knowledge learned by living and concretizing the abstract concepts.
\end{abstract}

Keywords: Science education, model, modeling, modeling skills, secondary school students.

\section{Giriş}

Model, karmaşık sistemleri yorumlamak için insanın zihninde var olan kavramsal yapılar ile bunların dış gösterimlerinin bir bütünüdür (Lesh ve Doerr, 2003). Dolayısıyla modeller aynı zamanda, soyut kavramları somutlaştıran sistemlerdir (Ingham ve Gilberts, 1991). Öğrencilerin derslerde anlamadığı konuları kavrayabilmesi için mühim olan modelleme sürecinin sınıf içerisinde kullanmasının önemi araştırmacılar tarafından da vurgulanmıştır (Arslan, 2013; Demirçalı, 2016; Doruk, 2010; Düşkün, 2011; Gözmen, 2008; Özdemir, 2017; Ünal-Çoban, 2009; Zeynelgiller, 2006).

Modelleme aracılığı ile öğrencilerde etkili fen öğretimi gerçekleştirilmesi, ilgili literatürde araştırmacıları fen eğitimindeki becerilere yöneltmiştir. Yani fen eğitiminde yer alan beceriler ne kadar iyi geliştirilebilirse, kavramsal boyutta öğrenme de o kadar başarıları olacaktır. Bu bağlamda fen eğitiminde yer alan beceriler; eleştirel düşünme becerileri, yaratıcı düşünme becerileri ve bilimsel süreç becerileri olmak üzere üçe ayrılmıştır (Fisher, 2005; Soylu, 2004; Wilson ve Wing Jan, 1993). Tablo 1'de bu becerilere ait özelliklere kısaca yer verilmiştir.

Tablo 1 incelendiğinde, öğrencilerin eleştirel düşünme becerilerinin on kategoriye, yaratıcı düşünme becerilerinin dört kategoriye, bilimsel süreç becerilerinin ise 12 kategoriye ayrıldığı görülmektedir. Yine Tablo 1 'de her üç becerinin de farklı sınıflandırmaya sahip olmasına rağmen, birbirleri ile ilişkili olduğu ifade edilebilir. Örneğin, eleştirel düşünme becerisinin altında yer alan hipotez oluşturma becerisi aslında bilimsel süreç becerilerinin altında yer alan hipotezi formüle etme becerisi ile 
ilişkilidir. Yani öğrenci öncelikle eleştirel düşünme becerisinin söz konusu özelliğine sahip olursa daha sonra bilimsel süreç becerilerinde yer alan hipotezi formüle etme becerisini sağlayabilecektir. Bunun dışında bilimsel süreç becerilerinin öğrencilerde oluşabilmesi için, öğrencilere deneyde yer alan araç gereçleri tanıma ve bunları kullanma gibi bazı teknik becerilerin deney öncesinde kazandırılmış olması gerekmektedir (Çepni ve Çil, 2009; Ayvacı ve Yılmaz, 2009; Ayvacı ve Bakırc1, 2012).

Tablo 1

Fen Eğitiminde Yer Alan Beceriler

\begin{tabular}{lll}
\hline \multicolumn{1}{c}{ Eleştirel Düşünme Becerileri } & \multicolumn{1}{c}{ Yaratıcı Düşünme Becerileri } & \multicolumn{1}{c}{ Bilimsel Süreç Becerileri } \\
\hline 1. İnceleme & 1. Akıcılık & 1. Sinıflama \\
2. Açılama & 2. Esneklik & 2. Model yapma \\
3. Örgütleme & 3. Orijinallik & 3. Hipotezi formüle etme \\
4. Mantık yürütme & 4. Detaylandırma & 4. Değiskenleri Belirleme \\
5. Hipotez oluşturma & (Fisher, 2005) & 5. Değişken türünü belirleme \\
6. Tahmin etme & & 6. Kullanılacak araç-gereçleri \\
7. Analiz & & 7. Tahmin yapma \\
8. Sentez & & 8. Gözlem yapma \\
9. Değerlendirme & 9. Veri analizi \\
10. Genelleme & 10. Sonuç çıarma \\
(Wilson ve Wing Jan, 1993) & & 11. Sonucu test etme \\
& & 12. Genelleme yapma \\
& & (Soylu, 2004) \\
\hline
\end{tabular}

Fen eğitiminde yer alan bu beceriler, modelleme becerilerinin doğmasına sebep olmuştur. İlgili literatürde modelleme becerileri, öğrencilerin modelleme sürecinde sahip olması gereken beceriler şeklinde tanımlanmaktadır (Harrison ve Treagust, 2000; Huguet, Erschler, De Terssac ve Lompré, 1996; Maaß, 2007). Bunlar; iletişim, müdahale, değerlendirme, problemi anlama, değişkenleri seçme, model kurma, problem çözme, çözümü yorumlama, modeli doğrulama, modeli başka problem durumlarına uygulama ve rapor yazma gibi becerileridir. Söz konusu becerileri daha iyi betimleyebilmek için literatürde fen eğitiminde yapılan modelleme ile ilgili çalışmaların daha ayrıntılı incelenmesi gerekir.

Literatürde fen eğitiminde modellemeye yönelik çalışmalara bakıldığında daha çok belirlenen bir durum, olay ya da bir veya birkaç kavramın öğretiminde modellemenin kullanılmasına yönelik çalışmalar yer almaktadır (Aktan, 2005; Borges ve Gilbert, 1999; Coll ve Treagust, 2003; Demir ve Namdar, 2019; Düşkün, 2011; Ergün ve Sarıkaya, 2019; Güneş, Bağcı ve Gülçiçek, 2004, İnal ve Aydın, 2015). Örneğin Coll ve Treagust (2003) metalik bağlar konusundaki zihinsel modellerini belirlemeye yönelik lise ve üniversite öğrencileri ile mezun olmuş bireylerden oluşan 24 kişilik bir grupla çalışmasını yürütmüştür. Çalışmada orta ve yükseköğretim düzeyindeki öğrenciler ile mezun olmuş bireylerin metal bağlarına ilişkin zihinsel modelleri belirlemeyi amaçlayan araştırmacılar, öğrencilerle klinik mülakatlar yapmıştır. Çalışmanın sonucunda ise, üniversite öğrencileri ve mezun bireylerin, metal bağlarına ilişkin tecrübelerinin yüksek olduğu, bununla birlikte her üç gruptaki bireylerin model tercihlerinin basit ya da gerçekçi modellere yönelik olduğu tespit edilmiştir. Demir ve Namdar (2019) beşinci sınıf düzeyinde öğrenim gören 17 öğrenci ile gerçekleştirdikleri 
araştırmalarında, yürütülen modelleme etkinliklerinin öğrencilerin gerçek yaşam durumlarına ilişkin informal muhakemelerine olan etkisini incelemişlerdir. Araştırma kapsamında, modelleme etkinlikleri öncesinde öğrencilerin daha çok sezgisel ve duygusal muhakemeler gerçekleştirdiklerini ifade eden araştırmacılar, modelleme etkinlikleri sonrasinda bireylerin akılcı ve duygusal muhakemeler gerçekleştirdiklerini belirtmiştir. Ergün ve Sarıkaya (2019) ise modele dayalı öğrenmenin ortaokul öğrencilerinin maddenin tanecikli yapısı konusundaki kavramsal anlamalarına ve akademik başarılarına olan etkisini incelemişleridir. Araştırmaya altıncı, yedinci ve sekizinci sınıf düzeyinden toplam 100 öğrenci katılmıştır. Araştırma sonucunda sınıf düzeyi fark etmeksizin modele dayalı öğrenmenin akademik başarıya olumlu yönde etkisinin olduğu, bunun yanında kavramsal anlamaya daha yüksek bir etkide bulunduğu tespit edilmiştir. Benzer şekilde İnal ve Aydın'ın (2015) yürütmüş oldukları çalışmada da ortaokul öğrencilerinin model etkinlikleri sonrasında Madde ve Isı ünitesine ait kavramların daha uzun süre akıllarında kaldığı ve akademik başarılarının düzeylerinde gelişme gözlendiği belirtilmektedir. Yukarıdaki çalışmalarda da (Aktan, 2005; Borges ve Gilbert, 1999; Coll ve Treagust, 2003; Düşkün, 2011; Güneş, Bağc1 ve Gülçiçek, 2004) ifade edildiği gibi öğrencilerde zihinsel modellerin oluşması ve bunun incelenmesine yönelik çalışmaların dişında, öğretmenlerin de söz konusu modellere yönelik görüşlerinin belirlenmesi de önemlidir. Güneş ve arkadaşları (2004) fen bilimlerinde kullanılan modellerle ilgili öğretmen görüşlerinin tespit edilmesi amaciyla yürüttükleri çalışmada, toplam 98 fizik, kimya, biyoloji, fen bilgisi ve matematik öğretmenin modellerin kendi derslerindeki önemlerine, gerekliliğine ve hangi amaçlarla kullandıkları konularına büyük oranda doğru görüş bildirdiklerini ifade etmiştir. Cheng, Wu ve Lin (2019), 608 dokuzuncu sınıf öğrencisi ile 95 fen bilimleri öğretmeni ile yürüttükleri çalışmada, bilimsel modeller ile modelleme süreci arasındaki ilişkiyi incelemiş, öğretmenlerin daha üst düzey bilimsel modellere sahip olmalarına rağmen, tıpkı öğrencilerdeki gibi model üretme sürecinde problemler yaşadıklarını ifade etmiştir.

Sonuç olarak, literatürde yer alan çalışmaların ortak amacı öğrencilere kavramsal boyutta fen öğretimini öğretmeyi sağlarken modellemeyi öğretimde bir araç olarak kullanmaktır. Bu kapsamda bazı çalışmalar modellemeye dayalı fen öğretimine vurgu yaparken (Araya vd., 2012; Bamberger ve Davis, 2013; Bat1, 2014; Bilgin ve Geban, 2001; Campbell, Zhang ve Neilson, 2011; Demir ve Namdar, 2019; Düşkün, 2011; Erduran, 1999; Ergün ve Sarıkaya, 2019; İnal ve Aydın, 2015; OganBekiroğlu, 2007; Schwarz vd., 2009; Taylor, Barker ve Jones, 2003; Vosniadou, 2002; Wells, Hestenes ve Swackhamer, 1994), bazı araştırmalar ise öğrencilerin ya da öğretmenlerin sahip olduğu zihinsel modellere vurgu yapmıştır (Aktan, 2005; Borges ve Gilbert, 1999; Cheng vd., 2019; Coll ve Treagust, 2003; Düşkün, 2011; Güneş vd., 2004). Çok az sayıda çalışma ise öğrencilerin modelleme sürecinde sahip olduğu becerilere vurgu yapmıştır (Kimura, 1999; Linn ve Petersen, 1985; French'ten aktaran Carroll 1993; Yıldız, 2009; Yolcu, 2008). Bu durum, öğrencilerin modelleme sürecini başarılı bir şekilde devam etmesine engel teşkil edebilmektedir. Yani eğer öğrencilerin modelleme sürecinde hangi becerilere sahip olması gerektiği bilinirse, öğretim süreci de bu becerileri merkeze alarak gerçekleştirilebilir. İlgili literatür, öğrencilerin modelleme sürecinde sahip olması gereken becerileri farklı şekillerde sınıflandırmıştır 
(Harrison ve Treagust, 2000; Huguet vd., 1996; Maaß, 2007). Bunlar; iletişim, müdahale, değerlendirme, problemi anlama, değişkenleri seçme, model kurma, problem çözme, çözümü yorumlama, modeli doğrulama, modeli başka problem durumlarına uygulama ve rapor yazma gibi becerilerdir. Literatürde belirlenen bu becerilere bakıldığında, oldukça genel olduğu görülmektedir. Diğger yandan bu genel becerilerle birlikte fen derslerinde model kullanımını etkili bir şekilde yürütebilmek için model oluşturma sürecine ve bu sürece özel becerilere hâkim olabilmek gerekmektedir. Öğrencilerin birer bilim insanı gibi zihinsel üretim süreçlerine girmesi, okulda ya da evinde merak ettiği olgulara yönelik deneysel gözlemleri yapabilmesi için nasıl bilimsel süreç becerilerine (Ayvacı ve Bakırc1, 2012; Ayvacı ve Yılmaz, 2009; Çepni ve Çil, 2009) hâkim olması gerekiyorsa, modelleme sürecinin de kendine özgü bu zor sürecinin kolaylaştırılabilmesi ve süreç sonunda anlamlı ve etkili ürünler oluşturulabilmesi için modelleme sürecine has becerilerin ortaya konulması ve bunların öğrencilere aktarılması gerekmektedir. Bu yüzden modelleme becerilerinin daha da özelleştirilmesi gerektiği düşünülmektedir. Hem literatürde yer alan bu açı̆̆1 kapatmak hem de öğrencilerin modelleme sürecini istekli ve bilişsel düzey seviyesine uygun şekilde yürütebilmesi için (Sins vd., 2005; Svoboda ve Passmore, 2013) öğrencilerin modelleme süreci sırasında kullanmaları gereken becerilerin neler olduğuna ilişkin bir çalışmaya ihtiyaç olduğu görülmektedir. Dolayısıyla bu çalışmanın amacı ortaokul ögrrencilerinin modelleme sürecinde ihtiyaç duydukları becerilerin belirlenmesidir.

\section{Yöntem}

$\mathrm{Bu}$ araştırmanın temel amacı, Fen Bilimleri dersi öğretim programı çerçevesinde yer alan modelleme etkinliklerinin geliştirilmesi sırasında öğrencilerin kullanmaları muhtemel modelleme becerilerinin tespit edilmesidir. Bu doğrultuda, nitel araştırma yöntemlerinden özel durum çalışması yöntemi kapsamında araştırma yürütülmüştür. Özel durum çalışması yöntemi, belirli sayıda değişkeni araştırmak, belirli süreçleri ve kuralları takip etmek yerine tek bir durumun derinlemesine incelenmesi olarak tanımlanmaktadır (Davey, 1991). Araştırmada derinlemesine incelenen durum olan modelleme becerilerin belirlenmesi için veri çeşitliliğine önem verilmiştir. Çünkü Marshall ve Rossman (2006), Merriam (2013) ve Yin (2009) durum çalışması kullanılan araştırmalarda veri çeşitliliğinin sağlanmasının, çalışma için gerekli olduğunu vurgulamışlardır. Bu bağlamda modelleme becerilerinin belirlenmesi sürecinde alan notları ve mülakatlar işe koşulmuş, bunlardan elde edilen veriler içerik analizi yöntemiyle derinlemesine analiz edilmiştir.

\section{Pilot Uygulama}

Pilot çalışma dönemi 2014-2015 eğitim öğretim y1lı bahar döneminde gerçekleştirilmiş olup, her biri beş hafta süren iki modelleme çalışmasını içeren toplam 10 haftadan oluşmaktadır. Bu süreç Trabzon ili merkez ilçesinde yer alan bir ortaokulda yürütülmüştür. Pilot çalışmaya seçmeli Bilim Uygulamaları dersini alan 27 beşinci sınıf, 22 altıncı sınıf ve 18 yedinci sınıf olmak üzere 67 öğrenci katılmış olup, bu kapsamda yapılandırılmamış gözlemler ve mülakatlar yürütülmüş ve asıl çalışmada kullanılacak yarı yapılandırılmış mülakat soruları geliştirilmiştir. Mülakat soruları hazırlanırken, pilot çalışmada yer almayan başka iki grup ortaokul öğrencisi ile modelleme çalışması gerçekleştirilmiş ve kayıt altına alınmıştır. Araştırmacılar bu 
süreci hem bireysel olarak hem de birlikte izleyerek, öğrencilerde incelenmesi gereken davranışların bir listesini hazırlamış ve bunları inceleyeme yönelik sorular oluşturmuştur. Bunun yanında bir fen bilimleri alan uzmanı, araştırmacılardan bağımsız olarak kayıtları ve oluşturulan taslak mülakat sorularını incelemiştir. Bu şekilde yarı yapılandırılmış mülakat sorularına son hali verilmiştir. TEOG sınavları, Bilim Uygulamaları dersini seçen öğrenci sayısının az oluşu ve Fen Bilimleri dersi öğretim programında yer alan modelleme kazanımı sayısının az olması göz önünde bulundurularak sekizinci sınıf öğrencileri hem pilot uygulamaya hem de asıl uygulamaya dâhil edilmemiştir.

\section{Asil Uygulama}

Asıl uygulama 2015-2016 güz yarıyılında yine aynı okulda yürütülmüştür. Pilot uygulama kapsamında elde edilen veriler neticesinde modelleme süreçleri üç haftaya düşürülmüştür. Asıl uygulamaya pilot uygulama ile aynı okulda öğrenim gören, pilot uygulama sürecine katılmamış 17 beşinci sınıfta, 22 altıncı sınıfta ve 18 yedinci sınıfta öğrenim gören toplam 57 öğrenci katılmıştır. Öğrencilerin Seçmeli Bilim Uygulamaları dersi kapsamında farklı şubelerden bir araya gelmeleri sebebiyle, gruplarını kendileri oluşturmaları istenmiştir. Böylece çalışma süreci olumsuz etkileyebilecek öğrencilerin birbirine alışma süreci ortadan kaldırılmaya çalışılmıştır. Gruplar üç ya da dört öğrenciden oluşmaktadır. Beşinci sınıf düzeyinde oluşturulan beş gruptan ikisi ağız modeli, üçü ise sindirim sistemi modeli; altıncı sınıf düzeyinde oluşturulan altı gruptan ikisi solunum sistemi modeli, ikisi hücre modeli, bir grup Dünya'nın katmanları modeli ve son grup Dünya-Güneş-Ay modeli; yedinci sınıf düzeyinde oluşturulan beş gruptan üçü atom modeli ve diğer iki grup ise molekül modeli yaparak asıl çalışmaya katılmışlardır. Bu modellerin dağıtılmasında öğrencilerin tercihleri ve kazanım seviyelerine uygunlukları dikkate alınmış, model konuları öğrencilere bu unsurlar gözetilerek verilmiştir. Gruplara ve gerçekleştirdikleri modellere ilişkin özet Tablo 2' de yer almaktadır.

Tablo 2

Modelleme Becerilerin Belirlenmesi Sürecinde Yapılan Modeller

\begin{tabular}{cccc}
\hline Gruplar & Beşinci Sınıf & Altıncı Sınıf & Yedinci Sınıf \\
\hline Grup 1 & Sindirim Sistemi Modeli & Solunum Sistemi Modeli & Atom Modeli \\
\hline Grup 2 & Sindirim Sistemi Modeli & Hücre Modeli & Atom Modeli \\
\hline Grup 3 & Ağız Modeli & Hücre Modeli & Atom Modeli \\
\hline Grup 4 & Sindirim Sistemi Modeli & Solunum Sistemi Modeli & Molekül Modeli \\
\hline Grup 5 & Ağız Modeli & Dünya'nın Katmanları Modeli & Molekül Modeli \\
\hline Grup 6 & - & Dünya-Güneş-Ay Modeli & - \\
\hline
\end{tabular}

Modelleme becerilerinin tespitine yönelik uygulama süreci aşağıda verilen Tablo 3'te gösterilmiştir. Asıl uygulama, üç haftalık bir süreci kapsayan modelleme etkinliğinin iki kez tekrar edilmesi ile toplam altı haftadan oluşmaktadır. 
Tablo 3

Modelleme Becerilerinin Tespitine Yönelik Uygulama Süreci

\begin{tabular}{lll}
\hline & \multicolumn{1}{c}{ Uygulama } & \multicolumn{1}{c}{ Ödev } \\
\hline 1. Hafta & Ön bilgileri yoklama, Konuya karar verme & Araştırma yapma, Model planı hazırlama \\
\hline 2. Hafta & $\begin{array}{l}\text { Malzemeleri Sorgulama, Modelleme } \\
\text { süreci sorgulama }\end{array}$ & Modeli karşılaştırma \\
\hline 3. Hafta & Modelin son halini görme & Modeli düzenleme \\
\hline
\end{tabular}

\section{Veri Toplama Araçları}

Ortaokul öğrencilerinin modelleme becerileri belirlenmesine yönelik yürütülen bu çalışmada veri toplama araçları olarak öğrencilere yönelitilen mülakat soruları ve araştırmacı alan notları kullanılmıştır. Öğrencilerin modelleme yapmadan önce hangi becerilerini kullandığının bir listesini yapmak üzere hazırlanan yarı yapılandırılmış mülakat soruları kısaca aşağıda özetlenmiştir.

- Model yapalım dediğimizde aklına ilk gelen şey nedir?

- Modelini nasıl yapmayı düşünüyorsun? Modelini yaparken kullanacağın malzemeleri seçerken hangi özelliklerine dikkat ediyorsun? Neden?

- Kullanacă̆ın malzemenin yapısı mi işlevi mi görünüşü mü önemli?

- ...kavramının hangi özelliğini modelleyeceksin? Hangi kısımlarının modelinde yer almasını düşünüyorsun? Bu kısımlar için hangi malzemeleri kullanmayı planlıyorsun? Seçtiğin malzemeler bu kısımlarla uyumlu mu?

- Yaptı̆̆ın modelin boyutları önemli mi? Buna neye göre karar veriyorsun?

- Modeli yapmaya hangi kısmından başlayacaksın? Başka kısımlardan başlarsan modelini geliştirmede bir sorun oluşturur mu?

- Modelin kısımlarında kullandığın malzemenin bir önemi var mı? Neden bu malzemeyi seçtin? Bu malzemenin yerine başka neler kullanabilirsin?

- Modelini tasarlarken ilk olarak nereden başladın?

- Modeli oluştururken seçtiğin malzemelerin yanında araç-gereç kullanacak mısın? Neden bu araç-gereçleri seçtin? Bu araç-gereçler olmadan modeli tamamlaman mümkün mü? Bu araç-gereçleri seçerken kullanacağın malzemelerin ne olduğunun bir önemi var mı?

Görüldüğü gibi yarı yapılandırılmış mülakat sorularında yer alan ifadeler, öğrencilerin modelleme sürecini yansitarak modelleme becerilerini ortaya koymaya çalışan bir niteliktedir. Bu sorular ile grup mülakatları gerçekleştirilerek veri toplanmıştır. Bir diğer veri toplama aracını ise modelleme sürecinde sürekli öğrencilerin arasında gezen ve onlara rehberlik yapan araştırmacıların alan notları oluşturmaktadır. Dolayısıyla araştırmacılar öğrencilerin tasarladığı modellerin amacı, gerekliliği, kullanılan malzeme vb. özelliklerini dikkate alarak sahip olduğu modelleme becerilerini ortaya çıkarmak için alan notu tutmuştur.

\section{Verilerin Analizi}

Araştırma kapsamında modelleme sürecinde öğrencilerle gerçekleştirilen mülakatlar ve araştırmacı alan notları içerik analizi ile incelenmiştir. Araştırma kapsamında grup mülakatlarından ve alan notlarından elde edilen veriler, elektronik ortama aktarılmıştır. Elde edilen veriler analiz edilerek ortaokul öğrencilerinin modellerini yaparken sergiledikleri davranışlara ilişkin kodlar oluşturulmuştur. Bu davranışları 
sergileyen öğrenciler ise frekans ve bulunduğu gruptaki öğrenci sayısına oranla yüzde şeklinde belirlenmiştir. Bu davranış kodları daha sonra gruplandırılarak, o davranışların hangi becerilere yönelik olduğuna dair bir temalandırma yapılmıştır. Oluşturulan davranış kodlarının, gruplandırıldığı beceri teması hakkında şüpheye düşülen durumlarda, o davranışı sergileyen öğrenciye başvurulmuş ve bu şekilde katılımcı teyidi sağlanmaya çalışılmıştır. Bu şekilde grup mülakatlarından elde edilen veriler ile öğrencilerin zihnindeki süreçler ve gerçekleştirmiş olduğu davranışlar ortaya konulmuştur. Ayrıca araştırmacı alan notlarından da öğrencilerin psikomotor davranışları ile süreç içerisinde gerçekleştirdiği davranışlar ile mülakattan elde edilen veriler desteklenmeye çalışılmıştır.

\section{Bulgular}

Araştırma kapsamında asıl uygulamadan elde edilen veriler içerik analizine tabi tutulduktan sonra modelleme için zihinsel becerilere ait bulgular ve modelleme için süreçsel becerilere ait bulgular olmak üzere iki başlık halinde verilmiştir.

\section{Modelleme İçin Zihinsel Becerilere Ait Bulgular}

Modelleme becerilerinin belirlenmesi amacıyla gerçekleştirilen modelleme etkinliklerinden elde edilen verilerin analizi sonucu, öğrencilerin zihinsel beceriler başlığı altında ilk beceriye ait gözlemlenen davranışları ve bu davranışı sergileyen öğrencilerin frekans ve yüzdeleri Tablo 4 'te gösterilmiştir.

Tablo 4

Uzamsal Becerilere (Uzamsal Görselleştirme, Uzamsal Algılama, Uzamsal Rotasyon) Yönelik Belirlenen Davranışlar

\begin{tabular}{|c|c|c|c|}
\hline Gözlemlenen Davranışlar & Öğrenciler & Frekans & $\begin{array}{l}\text { Gösterge } \\
\text { Yüzdesi }\end{array}$ \\
\hline $\begin{array}{l}\text { Cisimleri çizime } \\
\text { dönüştürme }\end{array}$ & $\begin{array}{l}\text { Ö5, Ö6, Ö7, Ö8, Ö15, Ö16, Ö17, Ö22, Ö23, Ö24, } \\
\text { Ö25, Ö37, Ö38, Ö39, Ö48, Ö49, Ö50, Ö51, Ö52, } \\
\text { Ö53, Ö54 }\end{array}$ & 21 & $\% 37$ \\
\hline $\begin{array}{l}\text { Çizimleri modele } \\
\text { dönüştürme }\end{array}$ & $\begin{array}{l}\text { Ö5, Ö6, Ö7, Ö8, Ö15, Ö16, Ö17, Ö18, Ö19, Ö20, } \\
\text { Ö21, Ö22, Ö23, Ö24, Ö25, Ö48, Ö49, Ö50, Ö51, } \\
\text { Ö52, Ö53, Ö54 }\end{array}$ & 22 & $\% 39$ \\
\hline $\begin{array}{l}\text { Cisim etrafında hareket } \\
\text { ederek gözlemleme }\end{array}$ & $\begin{array}{l}\text { Ö5, Ö6, Ö7, Ö8, Ö15, Ö16, Ö17, Ö22, Ö23, Ö24, } \\
\text { Ö25, Ö48, Ö49, Ö50, Ö51, Ö55, Ö56, Ö57 }\end{array}$ & 18 & $\% 32$ \\
\hline $\begin{array}{l}\text { Cismi hareket ettirerek } \\
\text { gözlemleme }\end{array}$ & $\begin{array}{l}\text { Ö5, Ö6, Ö7, Ö8, Ö15, Ö16, Ö17, Ö22, Ö23, Ö24, } \\
\text { Ö25, Ö26, Ö27, Ö28, Ö29, Ö37, Ö38, Ö39, Ö48, } \\
\text { Ö49, Ö50, Ö51, Ö55, Ö56, Ö57 }\end{array}$ & 25 & $\% 44$ \\
\hline $\begin{array}{l}\text { Cismi zihninde } \\
\text { canlandırarak farklı açılarda } \\
\text { düşünme }\end{array}$ & $\begin{array}{l}\text { Ö5, Ö6, Ö7, Ö8, Ö15, Ö16, Ö17, Ö22, Ö23, Ö24, } \\
\text { Ö25, Ö26, Ö27, Ö28, Ö29, Ö48, Ö49, Ö50, Ö51, } \\
\text { Ö55, Ö56, Ö57 }\end{array}$ & 22 & $\% 39$ \\
\hline $\begin{array}{l}\text { Çizimi zihninde } \\
\text { canlandırarak farklı açılarda } \\
\text { düşünme }\end{array}$ & $\begin{array}{l}\text { Ö5, Ö6, Ö7, Ö8, Ö15, Ö16, Ö17, Ö22, Ö23, Ö24, } \\
\text { Ö25, Ö26, Ö27, Ö28, Ö29, Ö48, Ö49, Ö50, Ö51, } \\
\text { Ö55, Ö56, Ö57 }\end{array}$ & 22 & $\% 39$ \\
\hline
\end{tabular}

Tablo 4 incelendiğinde, öğrencilerin uzamsal becerilerine ait davranışlarının genel olarak cisimlerin zihinde canlanması, tasarlanan çizimlerin modele dönüştürülmesi ya da modellerin çizimlere dönüştürülmesi ile cisimlerin farklı açılardan dönüşümlerinin gözlenmesi şeklinde olduğu görülmektedir. Bir başka 
deyişle uzamsal becerilerin, öğrencilerin üç boyutlu şekilleri iki boyuta ya da iki boyutlu şekilleri üç boyuta dönüştürmesi ile ilgili olduğu söylenebilir. Gözlemlenen bu davranışların bir örneği aşağıdaki öğrenci grubunun yaptığı modelleme aracılığıla verilmiştir.
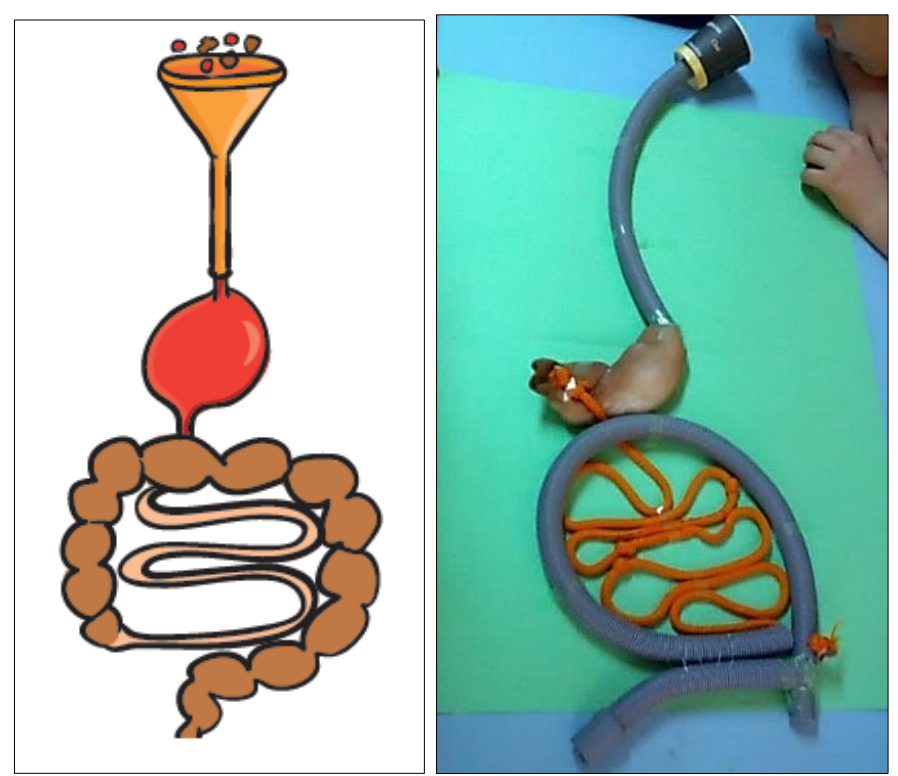

Şekil 1. Ö5, Ö6, Ö7 ve Ö8 kodlu öğrencilerin sindirim sistemi için kullandıkları taslak ve oluşturdukları model

Şekil 1 incelendiğinde, ortaokul öğrencilerinin sindirim sistemini modelledikleri görülmektedir. Öğrencilerin modelleri incelendiğinde, sindirim sisteminde yer alan organların üç boyutlu olmalarını sağlamaya çalıştıkları görülmektedir. Öğrenciler bu modellemeyi gerçekleştirirken taslak olarak ders kitaplarında yer alan sindirim sistemi modelini doğrudan kullanmışlardır. Özellikle sindirim kanalları, mide gibi organları modellerken düz zemin üzerinde daha belirgin olmasını sağlayacak malzemeler seçtikleri, mide ve pankreasın şişkin durabilmesini sağlamak için içine pamuk doldurdukları görülmektedir. Öğrenciler kâğıt üzerinde yer alan iki boyutlu taslaklarını üç boyutlu bir şekilde göstermeye çalıştıkları ve bunda da başarılı oldukları görülmektedir. Öğrencilerle modelleri üzerine gerçekleştirilen mülakattan bir kesit aşağıda verilmiştir.

A : Çocuklar modelinizle ilgili size bir şeyler sormak istiyorum. Sindirim sistemi modelinizde değişik bir model oluşturmuşsunuz. Neler yaptını biraz anlatın bakalım.

Ö5 : Öğretmenim organlarmızı modelledik. Kitapta yer alan resimdekine benzesin istedik. Değiişik malzemeler kullandik bunun için. Mesela yemek borusu için hortum. İşte mideye kadın çorabı yaptık, içine pamuk koyduk.

A : İçine neden pamuk koydunuz?

Ö5 : İçine pamuk koymazsak kabarık durmaz ki. Öğretmenimiz derste midemizin balon gibi, poşet gibi olduğunu söylemişti. O yüzden biz de kabarı dursun diye pamuk koyduk.

A : Ama kitabınızda düz bir şekilde gösteriyor. Siz bu taslağa göre yapmadınız mı? 
Ö6 : Tamam öğretmenim öyle yaptık da kitaptaki resim. Bizimki model olduğu için biz onu böyle göstermeliyiz. Yani gerçeğinde nasıl gözüküyorsa ona benzemeli. Düz bir şey olsa gerçekte öyle yapardık.

Yukarıda araştırmacı ve öğrenciler arasında geçen diyalog incelendiğinde, araştırmacının öğrencilerin taslaklarında (ders kitabındaki çizim) yer alan organlara modelleri üzerinde nasıl yer verdiklerini sorguladığı görülmektedir. Öğrencilerin taslakta düz zemin üzerinde iki boyutlu bir şekilde yer alan organları, üç boyutlu olmalarını sağlamak için çeşitli yolları denedikleri görülmektedir. Öğrenciler, her ne kadar kâğıt üzerinde yer alan taslakları iki boyutlu olsa da bunun aslında üç boyutlu bir hedefe ait olduğunun farkında oldukları, dolayısıyla modellerinin de hedefle uyumlu olması için üç boyutlu olması gerektiğini ifade ettikleri görülmektedir.

Öğrencilerin modelleme çalışmaları yürütürken "cisimleri çizime dönüştürme, çizimleri modele dönüştürme, cisim etrafında hareket ederek gözlemleme, cismi hareket ettirerek gözlemleme, cismi zihinde canlandırarak farklı açılarda düşünme, çizimi zihinde canlandırarak farklı açılardan düşünme" şeklinde davranışlar sergiledikleri görülmüştür. Birinci beceri olarak kodlanan bu davranışlar uzamsal beceriler olarak adlandırılmıştır. Elde edilen bulgular 1şı̆̆ında uzamsal becerilerin, uzamsal görselleştirme, uzamsal algılama ve uzamsal rotasyon becerileri olmak üzere üç alt beceriye ayrılmıştır. Uzamsal görselleştirme becerisinin göstergeleri, İki boyutlu çizimleri üç boyutlu nesnelere dönüştürür ve Üç boyutlu nesneleri iki boyutlu çizimlere indirger şeklinde, uzamsal alg1lama becerisinin göstergeleri, Sabit nesne etrafindaki hareketi sonucu meydana gelen geometrik değişimler arasında ilişki kurar son olarak uzamsal rotasyonun göstergeleri ise Nesnenin hareketi sonucu oluşacak değişiklikleri tahmin eder, İki boyutlu çizimlere ilişkin zihninde farkl açılara dönüşüm yapar, Üç boyutlu nesnelere ilişkin zihninde farklı yönlerde dönüşüm yapar şeklindedir.

Öğrencilerle yürütülen modelleme etkinliklerinin sonucunda belirlenen orijinal fikir üretme becerisine ait gözlemlenen davranışlar ve bu davranışı sergileyen öğrencilerin frekans ve yüzdeleri Tablo 5 'te gösterilmiştir.

Tablo 5

Orijinal Fikir Üretme Becerisine Yönelik Belirlenen Davranışlar

\begin{tabular}{llcc}
\hline \multicolumn{1}{c}{ Gözlemlenen Davranışlar } & Öğrenciler & Frekans & $\begin{array}{c}\text { Gösterge } \\
\text { Yüzdesi }\end{array}$ \\
\hline $\begin{array}{l}\text { Modele hazırlık sürecinde alışılagelmiş modeller dişında } \\
\text { bir taslak oluşturma }\end{array}$ & $\begin{array}{l}\text { Ö48, Ö49, Ö50, } \\
\text { Ö51 }\end{array}$ & 4 & $\% 7$ \\
\hline $\begin{array}{l}\text { Model taslağında malzeme seçiminde kırtasiye } \\
\text { malzemeleri dışında farklı malzemeleri tercih etme }\end{array}$ & Ö5, Ö6, Ö7, Ö8 & 4 & $\% 7$ \\
\hline $\begin{array}{l}\text { Modelini, benzer modellerden farklı bir biçimde } \\
\text { yorumlayarak oluşturma }\end{array}$ & Ö5, Ö6, Ö7, Ö8 & 4 & $\% 7$ \\
\hline $\begin{array}{l}\text { Modelini yaptığ kaynak nesnenin bir parçasını, benzer } \\
\text { modellerden farklı bir biçimde yorumlayarak oluşturma }\end{array}$ & Ö52, Ö53, Ö54 & 3 & $\% 5$ \\
\hline
\end{tabular}

Tablo 5 incelendiğinde, öğrencilerin orijinal fikir üretme becerisine ait davranışlarının genel olarak oluşturulan modelin diğerlerinden farklı olması, modeli hazırlarken kullanılan araç ve gereçlerin genel olarak kullanılan kırtasiye malzemelerinden farklı olması, modele yönelik hazırlanan taslağın diğerlerinden 
farklı olması şeklinde olduğu görülmektedir. Yani bu beceride daha çok kullanılan araç-gereçler ve yöntemlerde, yapılan modellerde farklılığın ön planda olduğu gözlenmiştir. Bu bağlamda gözlemlenen bu davranışların bir örneği aşağıdaki öğrenci grubunun yaptığı modelleme aracılığılyla verilmiştir.

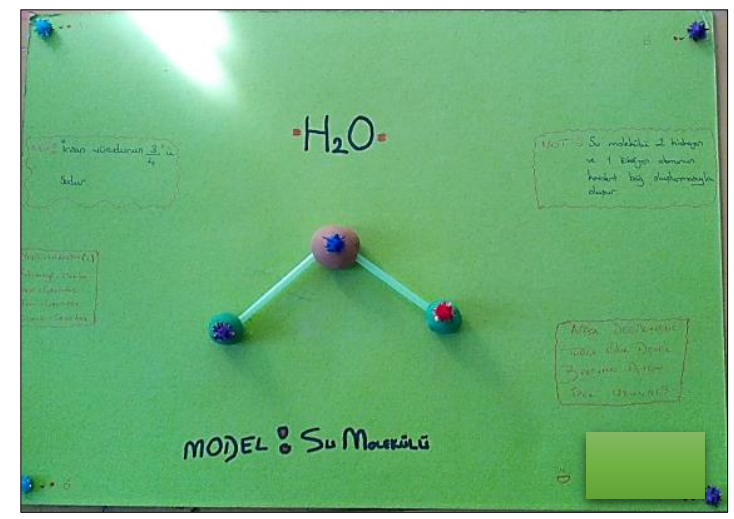

Şekil 2. Ö52, Ö53 ve Ö54 kodlu öğrencilerin yaptıkları su molekülü modeli

Şekil 2'de yedinci sınıf öğrencilerinden Ö52, Ö53 ve Ö54'ün modelleme becerilerinin belirlenmesi sürecinde oluşturmuş oldukları su molekülü modeline yer verilmiştir. Model incelendiğinde, öğrencilerin bir oksijen ve iki hidrojen atomundan oluşan su $\left(\mathrm{H}_{2} \mathrm{O}\right)$ molekülünü düz bir zemin üzerinde oluşturdukları görülmektedir. Öğrencilerin modelledikleri bu molekülde oksijen ve hidrojen atomlarını oyun hamurlarıyla, bu atomlar arasındaki bağları ise pipetlerle betimledikleri görülmektedir. Oyun hamurlarının üzerinde ise sadece görsel bir amacı olan ponponlara yer vermişlerdir. Öğrencilerin modelleri incelendiğinde, atomların etrafında yer alması gereken elektronlara yer vermedikleri, bunun yerine sadece molekülü oluşturan atomlara, molekül geometrisine dikkat ederek yer verdikleri görülmektedir. Öğrencilerin modellerinde, kaynak nesnenin tamamını modellemek yerine, amaçları doğrultusunda belirledikleri bir kısmı oluşturmayı ve bunu kendi yorumlarıyla ifade etmeye çalıştıkları görülmektedir. Yani öğrencilerin, daha önce belirlenen modeli yorumlayarak oluşturma davranışına benzer şekilde, modelini yaptığı kaynak nesnenin bir parçasını, benzer modellerden farklı bir biçimde yorumlayarak oluşturma davranışı gerçekleştirdiği belirlenmiştir.

Öğrencilerin benzer şekilde cevapları ve gözlemlenen davranışları incelendiğinde, ikinci beceri orijinal fikir üretme becerisi olarak isimlendirilmiştir. Bu kapsamda orijinal fikir üretme becerisinin göstergeleri, Modeli için rutin olmayan bir taslak çizer, Modeli için rutin olmayan malzemelere yer verir, Modelini genel geçer modellerden farklı bir şekilde yorumlar/oluşturur, Kaynak nesnenin bir parçasını genel geçer modellerden farklı bir şekilde yorumlar/oluşturur şeklindedir.

Araştırmada belirlenen analojik akıl yürütme becerisine ait gözlemlenen davranışlar ve bu davranışı sergileyen öğrencilerin frekans ve yüzdeleri Tablo 6 ' da yer verilmiştir. 
Tablo 6

Analojik Akıl Yürütme Becerisine Yönelik Belirlenen Davranışlar

\begin{tabular}{|c|c|c|c|}
\hline Gözlemlenen Davranışlar & Öğrenciler & Frekans & $\begin{array}{l}\text { Gösterge } \\
\text { Yüzdesi }\end{array}$ \\
\hline $\begin{array}{l}\text { Modelini oluştururken veya oluşturduktan } \\
\text { sonra, modeliyle daha önce oluşturduğu ya da } \\
\text { gözlemlediği modeller arasında benzerlik kurma }\end{array}$ & $\begin{array}{l}\text { Ö18, Ö19, Ö20, Ö21, } \\
\text { Ö44, Ö45, Ö46, Ö47, } \\
\text { Ö48, Ö49, Ö50, Ö51 }\end{array}$ & 12 & $\% 21$ \\
\hline Oluşturduğu modeli yeni durumlara test etme & $\begin{array}{l}\text { Ö5, Ö6, Ö7, Ö8, Ö22, } \\
\text { Ö23, Ö24, Ö25, Ö30, } \\
\text { Ö31, Ö32, Ö33, Ö37, } \\
\text { Ö38, Ö39 }\end{array}$ & 15 & $\% 26$ \\
\hline $\begin{array}{l}\text { Modelini çeşitli durumlarda test ettikten sonra } \\
\text { düzenleme ve yapılandırma }\end{array}$ & Ö37, Ö38, Ö39 & 3 & $\% 5$ \\
\hline
\end{tabular}

Tablo 6 incelendiğinde, analojik akıl yürütme becerisine yönelik davranışların oluşturulan modelin diğerleri ile ilişkilendirilmesi, modelin yeni durumlar üzerinde test edilmesi, modelin yeni durumlara uyarlanması şeklinde olduğu görülmektedir.

Araştırmacının öğrencilerin yerine getirmesi gereken modellerini diğer modellerle karşılaştırma ve düzenleme aşamasında neler yaptıklarını irdelediği görülmektedir. Bu doğrultuda araştırmacı ilk olarak öğrencilere modellerini başka modellerle karşılaştırmaları sonucu neler gözlemlediklerini sormuştur. Ö22 kodlu öğrencinin cevabına göre, yaptıkları modelin iki boyutlu bir model olduğu, bununla birlikte inceledikleri modellerin (EBA'daki hücre modelleri ve okul laboratuvarındaki hücre modelleri) ise üç boyutlu modeller olduğunu belirtmiş̧tir. Araştırmacının inceledikleri modeller kapsamında, modellerinde neden değişiklik yapmadığını sorması üzerine öğrencinin modeli daha basit bir şekilde oluşturmayı amaçladığı şeklinde cevap verdiği görülmektedir. Öğrencilerin model oluşturma sürecinde biraz kolaya kaçtıklarını fark eden araştırmacı, inceledikleri modeller kapsamında bir değişiklik planları olsaydı neler olurdu şeklinde bir soruyla öğrencilerin zihinlerindeki model uyarlama planlarında neler olabileceğini açığa çıkarmaya çalışmışır. Bu soruya öğrencilerin verdiği cevaplar incelendiğinde ise, modellerini üç boyutlu hale getirebilecekleri, farklı malzemelerle yeniden tasarlayabileceklerini söylediği görülmektedir. Sonuç olarak, öğrencilerin modellerini düzenleme işinden kaçındıkları, yine de geçmiş bir modelleme çalışmasından elde ettiklerini yeni duruma uygulayabileceklerini ifade ettikleri belirlenmiştir. Öğrencilerin modellerini test etme bağlamında sınırlı bir davranış sergilediği, sadece modellerini taslaklarında yer alan biçimde tamamlayarak modellerini son halini vermeyi amaçladıkları görülmektedir.

Üçüncü beceri kapsamında öğrencilerin daha çok yaptıkları modellerin farklı durumlara uyarlanması konusunda düşünce ve davranışlarını ifade ettiği söylenebilir. Dolayısıyla elde edilen bulgular ışı̆̆ında üçüncü beceri analojik akıl yürütme becerisi olarak isimlendirilmiştir. Analojik akıl yürütme becerisinin göstergeleri ise, Bir problem çözümüne yönelik olarak önceki deneyimleriyle benzerlik kurarak modelini yapılandırır. (Yakın transfer), Bir problemin çözümüne yönelik geliştirilen modeli yeni durumlara göre sinar ve model üzerinde uyarlama yapar (Uzak transfer) şeklindedir.

Zihinsel beceriler kapsamında araştırmada belirlenen yapısal ilişki eşleştirme becerisine ait gözlemlenen davranışlar ve bu davranışı sergileyen öğrencilerin frekans ve yüzdeleri Tablo $7^{\prime}$ da yer verilmiştir. 
Tablo 7

Yapısal İlişki Eşleştirme Becerisine Yönelik Belirlenen Davranışlar

\begin{tabular}{lllcc}
\hline \multicolumn{2}{c}{ Gözlemlenen Davranışlar } & \multicolumn{1}{c}{ Öğrenciler } & Frekans & $\begin{array}{c}\text { Gösterge } \\
\text { Yüzdesi }\end{array}$ \\
\hline $\begin{array}{l}\text { Oluşturulan model ile bu modelin } \\
\text { oluşturulduğu obje arasında bir ilişki } \\
\text { kurabileceği özellikleri tespit etme }\end{array}$ & $\begin{array}{l}\text { Ö5, Ö7, Ö8, Ö9, Ö10, Ö30, Ö31, Ö32, Ö33 } \\
\text { Ö11, }\end{array}$ & \%19 \\
\hline $\begin{array}{l}\text { Model ile bu modelin oluşturulduğu obje } \\
\text { arasında, sistemsel ilişki kurma }\end{array}$ & $\begin{array}{l}\text { Ö5, Ö6, Ö7, Ö8, Ö9, Ö10, } \\
\text { Ö11, Ö30, Ö31, Ö32, Ö33 }\end{array}$ & 11 & $\% 19$ \\
\hline
\end{tabular}

Tablo 7'de görüldüğgü gibi yapısal iliş̧i eşleştirme becerisine ait davranışlar oluşturulan model ile bu modelin oluşturduğu obje arasındaki ilişkiyi ve bu ilişkinin sistematikliğini kapsamaktadır. Ortaokul öğrencilerinin modelleme becerilerinin belirlenmesi sürecinde, gerçekleştirilen modelleme etkinlikleri sırasında öğrencilerin oluşturdukları model ile bu modellerini oluşturdukları nesneler arasında ilişki kurabileceği özellikleri tespit etmeye çalıştıkları belirlenmiştir. Belirlenen bu davranışa örnek bir modelleme etkinliğine aşağıda yer verilmiştir.

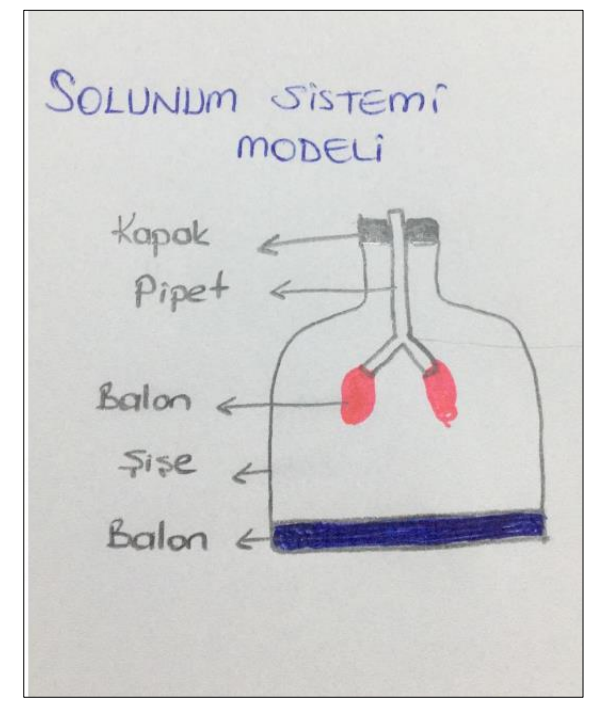

Şekil 3. Ö30, Ö31, Ö32 ve Ö33 kodlu öğrencilerin hazırladıkları solunum sistemi model taslağ 1

Şekil 3'te verilen taslak incelendiğinde, öğrencilerin solunum sistemi modelini yapmayı planladıkları görülmektedir. Taslağa göre öğrenciler, bir pet şişe içerisinde iki balonu pipetler yardımıyla dış ortama bağlayacaklardır. Pet şişenin açık olan alt tarafına ise yine bir balon geçirilip kapatılacaktır. Şişe hem alttan hem üstten kapatılarak hava almayacak bir şekilde yalıtılacaktır. Öğrencilerin gerçekleştirdiği bu model, sıkça karşılaşılan model örneklerinden bir tanesidir. Bu modelde akciğerleri şişenin içerisindeki balonlar, soluk borusu ve bronşları pipetler, diyaframı pet şişenin altında gerili şekilde duran balon ve göğüs kafesini ise pet şişe ile ifade eden öğrencilerle, hazırlamış oldukları modele ilişkin görüşmeler gerçekleştirilmiştir. Bu süreçte öğrencilerin hedef nesne olarak belirledikleri solunum sistemi organları ile bu hedef sistemde yer alan yapılardaki ilişkileri modellerindeki akciğeri niteleyen balonlara, göğüs kafesini niteleyen pet şişeye ve diyaframı niteleyen alttaki balonla 
kurmaya çalıştıkları tespit edilmiştir. Yani öğrencilerin modeli yaparken oluşturulan model ile bu modelin oluşturulduğu obje arasında bir ilişki kurabileceği özellikleri tespit etme davranışı gerçekleştirmişlerdir. Sonuç olarak öğrencilerin modelleme çalışmalarının incelenmesi ile dördüncü beceri yapısal ilişki becerisi olarak adlandırılmıştır. Bu bağlamda yapısal ilişki eşleştirme becerisinin göstergeleri, Model ya da model kısımları ile kaynak nesne ya da kaynak nesnenin kısımları arasında ilişkileri koruyabileceği yapılar belirler ve Model ya da modelin kısımlarn ile kaynak nesne ya da kaynak nesnenin kısımları arasında sistematik eşleşmeleri belirler şeklindedir.

\section{Modelleme İçin Süreçsel Becerilere Ait Bulgular}

Modelleme becerilerinin belirlenmesi amacıyla gerçekleştirilen modelleme etkinliklerinden elde edilen verilerin analizi sonucu, öğrencilerin süreçsel beceriler başlığı altında malzeme-araç ilişkisi kurma becerisine ait gözlemlenen davranışları ve bu davranışı sergileyen öğrencilerin frekans ve yüzdeleri Tablo 8'de gösterilmiştir.

Tablo 8

Malzeme-Araç İlişkisi Kurma Becerisine Yönelik Belirlenen Davranışlar

\begin{tabular}{|c|c|c|c|}
\hline Gözlemlenen Davranışlar & Öğrenciler & Frekans & $\begin{array}{l}\text { Gösterge } \\
\text { Yüzdesi }\end{array}$ \\
\hline $\begin{array}{l}\text { Modele uygun malzemeler için makas, cetvel, } \\
\text { falçata gibi araçları tanıma }\end{array}$ & $\begin{array}{l}\text { Ö1, Ö2, Ö3, ... Ö55, } \\
\text { Ö56, Ö57 }\end{array}$ & 57 & $\% 100$ \\
\hline $\begin{array}{l}\text { Modele uygun malzemeler için makas, cetvel, } \\
\text { falçata gibi araçları kullanmayı bilme }\end{array}$ & $\begin{array}{l}\text { Ö5, Ö6, Ö7, Ö8, Ö26, } \\
\text { Ö27, Ö28, Ö29, Ö30, } \\
\text { Ö31, Ö32, Ö33, Ö37, } \\
\text { Ö38, Ö39, Ö48, Ö49, } \\
\text { Ö50, Ö51 }\end{array}$ & 19 & $\% 33$ \\
\hline $\begin{array}{l}\text { Model kapsamında kullanacağı malzemeler ile } \\
\text { bu modele uygun kullandığı makas, cetvel ve } \\
\text { falçata gibi araçların oluşturduğu sorunları } \\
\text { bulma ve bu sorunların üstesinden gelme }\end{array}$ & $\begin{array}{l}\text { Ö5, Ö6, Ö7, Ö8, Ö30, } \\
\text { Ö31, Ö32, Ö33, Ö37, } \\
\text { Ö38, Ö39, Ö48, Ö49, } \\
\text { Ö50, Ö51 }\end{array}$ & 15 & $\% 26$ \\
\hline
\end{tabular}

Tablo 8'de öğrencilerin modelleme aşamasında tespit edilen ve süreçsel beceriler başlığı altında malzeme-araç ilişkisi kurma becerisine yönelik belirlenen davranışlarına yer verilmiştir. Bu davranışlar incelendiğinde genellikle, modele uygun malzemeler ve kullanılan araç gereçlerle ilgili olduğu görülmektedir. Öğrencilerde söz konusu bu becerilerin nasıl ortaya çıktığı bir mülakat örneği ile aşağıda açıklanmıştır.

A : Çocuklar, mukavvanın kenarlarn neden böyle oldu?

Ö5 : Öğretmenim biraz kötü oldu burası ya. Makasla kestik ondan biraz yırtık yırtık oldu kenarlart.

A : Düzgün de kesememişsiniz sanki

Ö7 : Evet, bize falçata lazım ama aklımıza gelmedi getirmek. Olsaydı çizdiŏimiz yerden dümdüz keserdik. Böyle hiç güzel olmadi.

Öğrencilerle gerçekleştirilen yukarıdaki görüşme örneği incelendiğinde, mukavva kesmek için makas kullanıldığı ve bunun sonucunda mukavvanın amaçlanan şekilde düzgün kesilemediği ifade edilmektedir. Araştırmacının, bu durumu sorduktan sonra, araç olarak makas yerine falçata kullanmaları gerektiği öğrenciler tarafından belirtilmektedir. Öğrenciler bu noktada ellerindeki araçları 
tanımalarına rağmen bu aracın hangi malzemelerle uyumlu olduğunu tam olarak belirleyememektedirler. Sonuç olarak elde edilen bulgular ışı̆̆ında birinci beceri, malzeme araç ilişkisi kurma becerisi olarak isimlendirilmiştir. Bu bağlamda malzeme araç ilişkisi kurma becerisinin göstergeleri, Model kapsamında kullanacağı malzemeler için gerekli araçları tanır, Model kapsamında kullanacağı malzemeler için gerekli araçları kullanmayı bilir, Model kapsamında kullanacă̆ı malzemeler ile kullanacağı araçlar arasındaki sorunlar tespit eder ve bu sorunları çözer şeklindedir.

Tablo 9 incelendiğinde malzeme-model ilişkisi kurma becerisine yönelik gözlenen davranışlar daha çok modelin yapıldığ1 malzeme ve kendisi arasındaki ilişkiye aittir. Modelleme becerilerinin belirlenmesi sürecinde gerçekleştirilen modelleme etkinliklerinde öğrencilerin seçilen malzemelerin kullanılacak modelin sertlik, sağlamlık gibi fiziksel özellikleri arasında ilişki kurma davranışı sergiledikleri belirlenmiştir.

Tablo 9

Malzeme-Model İlişkisi Kurma Becerisine Yönelik Belirlenen Davranışlar

\begin{tabular}{|c|c|c|c|}
\hline Gözlemlenen Davranışlar & Öğrenciler & Frekans & $\begin{array}{l}\text { Gösterge } \\
\text { Yüzdesi }\end{array}$ \\
\hline $\begin{array}{l}\text { Seçilen malzemelerin kullanılacak } \\
\text { modelin sertlik, sağlamlık gibi } \\
\text { fiziksel özellikleri arasında ilişki } \\
\text { kurma }\end{array}$ & $\begin{array}{l}\text { Ö5, Ö6 Ö7, Ö8, Ö9, Ö10, Ö11, } \\
\text { Ö26, Ö27, Ö28, Ö29, Ö34, Ö35, } \\
\text { Ö36, Ö37, Ö38, Ö39, Ö48, Ö49, } \\
\text { Ö50, Ö51, Ö52, Ö53, Ö54, Ö55, } \\
\text { Ö56, Ö57 }\end{array}$ & 27 & $\% 47$ \\
\hline $\begin{array}{l}\text { Model için seçilen malzemeler ile } \\
\text { modelin nasıl çalışacağını açıklama }\end{array}$ & $\begin{array}{l}\text { Ö5, Ö6 Ö7, Ö8, Ö9, Ö10, Ö11, } \\
\text { Ö30, Ö31, Ö32, Ö33 }\end{array}$ & 11 & $\% 19$ \\
\hline $\begin{array}{l}\text { Model oluşturmak için ucuz ve her } \\
\text { yerden kolayca ulaşılabilir malzeme } \\
\text { temin etme }\end{array}$ & Ö5, Ö6 Ö7, Ö8 & 4 & $\% 7$ \\
\hline $\begin{array}{l}\text { Belirlenen malzemelerin model ile } \\
\text { ilişkisini kurarken yaşanılan } \\
\text { sorunları tespit ederek üstesinden } \\
\text { gelme }\end{array}$ & $\begin{array}{l}\text { Ö5, Ö6 Ö7, Ö8, Ö37, Ö38, Ö39, } \\
\text { Ö48, Ö49, Ö50, Ö51 }\end{array}$ & 11 & $\% 19$ \\
\hline
\end{tabular}

Belirlenen bu davranışlara ait öğrencilerin verdikleri cevaplar incelendiğinde, ilk olarak belirledikleri malzeme olan topla denemenin başarısız olması sebebiyle, daha kolay şekil verilebilen oyun hamurunu tercih ederek modellerini oluşturduklarını ifade etmektedirler. Oyun hamurunun sağladığı diğer bir avantajın ise, kendi rengi olmasından dolayı boyama ihtiyacının ortadan kalkması olduğunu ifade eden öğrenciler, bu sebeplerden ötürü modellerinde oyun hamuruna yer verdiklerini belirtmiştir. Bununla birlikte araştırmacı, öğrencilerin hazırlamış oldukları bu modelde oyun hamuru ve pipet kullanmalarından ötürü sağlam olup olmadığını incelemiştir. Öğrenciler de modellerinde kullandıkları malzemelerden ötürü modellerinin dayanıklı bir yapıda olmadığının farkında olduklarını belirtmişlerdir. Yani öğrencilerin modelleme sürecinde seçilen malzemelerin kullanılacak modelin sertlik, sağlamlı gibi fiziksel özellikleri arasında ilişki kurma davranış1 sergiledikleri tespit edilmiştir.

Sonuç olarak malzeme model ilişkisi kurma becerisinin göstergeleri, Model için seçtiği malzemeler ile modelin fiziksel özellikleri arasında ilişki kurar, Model için seçtiği 
malzemeler ile modelin çalışma prensibi arasında ilişki kurar, Model için seçtiği malzemelerin ekonomik ve kolay bulunabilir olmasına dikkat eder, Belirlediği malzemelerin modeli ile ilişkisi noktasında sorunları tespit eder ve bunların nasıl giderileceğini bilir şeklindedir.

Araştırmanın süreçsel becerileri kapsamında belirlenen modele ilişkin araştırma yapma becerisine ait gözlemlenen davranışlar ve bu davranışı sergileyen öğrencilerin frekans ve yüzdeleri Tablo 10 'da yer verilmiştir.

Tablo 10

Modele İlişkin Araştırma Yapma Becerisine Yönelik Belirlenen Davranışlar

\begin{tabular}{|c|c|c|c|}
\hline Gözlemlenen Davranışlar & Öğrenciler & Frekans & $\begin{array}{l}\text { Gösterge } \\
\text { Yüzdesi }\end{array}$ \\
\hline $\begin{array}{l}\text { Model için gerçekleştireceği } \\
\text { araştırmanın sürecini bilme }\end{array}$ & $\begin{array}{l}\text { Ö1, Ö2, Ö3, Ö4, Ö5, Ö6, Ö7, } \\
\text { Ö8, Ö37, Ö38, Ö39, Ö48, Ö49, } \\
\text { Ö50, Ö51, Ö55, Ö56, Ö57 }\end{array}$ & 18 & $\% 32$ \\
\hline $\begin{array}{l}\text { Araştırma kapsamında kitaplar, ilgili } \\
\text { literatür tarama, videolar izleme gibi } \\
\text { hangi kaynaklardan yararlanacağını } \\
\text { bilme }\end{array}$ & $\begin{array}{l}\text { Ö1, Ö2, Ö3, Ö4, Ö5, Ö6, Ö7, } \\
\text { Ö8, Ö37, Ö38, Ö39, Ö55, Ö56, } \\
\text { Ö57 }\end{array}$ & 14 & $\% 25$ \\
\hline $\begin{array}{l}\text { Model için topladığı dokümanları } \\
\text { değerlendirerek sonuç çıkarma }\end{array}$ & $\begin{array}{l}\text { Ö1, Ö2, Ö3, Ö4, Ö5, Ö30, Ö31, } \\
\text { Ö32, Ö33, Ö37, Ö38, Ö39, Ö48, } \\
\text { Ö49, Ö50, Ö51, Ö55, Ö56, Ö57 }\end{array}$ & 19 & $\% 33$ \\
\hline
\end{tabular}

Tablo 10 incelendiğinde, modele ilişkin araştırma yapma becerisine ait davranışların modele yönelik araştırma yapmak ve bu araştırma sürecinin farkında olmak şeklinde olduğu görülmektedir. Bu davranışa yönelik öğrenciler gözlemlendiğinde genel olarak model yapmadan önce araştırma yaptıkları gözlenmiştir. Yalnız öğrenciler yaptıkları bu araştırmaları sadece kitap, sadece internet ya da sadece aile bireylerine sorma eğiliminde oldukları gözlenmiştir. Yani öğrenciler üçüncü beceriye ait davranışları daha çok olumsuz yönde sergilemişlerdir. Sonuç olarak, öğrencilerin sergilediği bu davranışlar bu araştırmada modele ilişkin araştırma yapma becerisi olarak isimlendirilmiştir. Bu becerinin göstergeleri ise, Modele ilişkin yapacağı araştırmanın basamaklarını bilir. Modele ilişkin yapacağı araştırma kapsamında yararlanacă̆ı kaynakları bilir, Modele ilişkin yaptığı araştırma kapsamında topladığı verileri analiz eder şeklindedir.

Süreçsel becerilerin sonuncusu ve araştırmada belirlenen model planı hazırlama becerisine ait gözlemlenen davranışlar ve bu davranışları sergileyen öğrencilerin frekans ve yüzdeleri Tablo 11'de yer verilmiştir.

Tablo 11 incelendiğinde, model planı hazırlama becerisinin model taslağı oluşturma, model taslağında kullanılacak malzemeleri belirleme ve modelleme sürecini planlama davranışlarından oluştuğu görülmektedir. Öğrenciler tarafından sergilenen bu davranışları daha detaylı inceleyebilmek için, bir grup öğrencinin yaptığı modelleme çalışmasına aşağıda yer verilmiştir. 
Tablo 11

Model Planı Hazırlama Becerisi Yönelik Belirlenen Davranışlar

\begin{tabular}{|c|c|c|c|}
\hline Gözlemlenen Davranışlar & Öğrenciler & Frekans & $\begin{array}{l}\text { Gösterge } \\
\text { Yüzdesi }\end{array}$ \\
\hline $\begin{array}{l}\text { Yapılacak modeli bir kâğıtta } \\
\text { çizerek taslağını oluşturma }\end{array}$ & $\begin{array}{l}\text { Ö1, Ö2, Ö3, Ö4, Ö9, Ö10, Ö11, Ö15, Ö16, Ö17, } \\
\text { Ö18, Ö19, Ö20, Ö21, Ö22, Ö23, Ö24, Ö25, Ö26, } \\
\text { Ö27, Ö28, Ö29, Ö30, Ö31, Ö32, Ö33, Ö34, Ö35, } \\
\text { Ö36, Ö37, Ö38, Ö39, Ö40, Ö41, Ö42, Ö43, Ö44, } \\
\text { Ö45, Ö46, Ö47, Ö48, Ö49, Ö50, Ö51, Ö52, Ö53, } \\
\text { Ö54, Ö55, Ö56, Ö57 }\end{array}$ & 51 & $\% 90$ \\
\hline $\begin{array}{l}\text { Oluşturulan model } \\
\text { taslağında hangi } \\
\text { malzemelerin ve araçların } \\
\text { kullanılacağını belirler }\end{array}$ & $\begin{array}{l}\text { Ö9, Ö10, Ö11, Ö18, Ö19, Ö20, Ö21, Ö26, Ö27, } \\
\text { Ö28, Ö29, Ö30, Ö31, Ö32, Ö33, Ö37, Ö38, Ö39, } \\
\text { Ö55, Ö56, Ö57 }\end{array}$ & 21 & $\% 37$ \\
\hline $\begin{array}{l}\text { Modelleme sürecini } \\
\text { planlama }\end{array}$ & $\begin{array}{l}\text { Ö5, Ö6, Ö7, Ö8, Ö9, Ö10, Ö11, Ö26, Ö27, Ö28, } \\
\text { Ö29, Ö37, Ö38, Ö39, Ö48, Ö49, Ö50, Ö51, Ö55, } \\
\text { Ö56, Ö57 }\end{array}$ & 21 & $\% 37$ \\
\hline
\end{tabular}

Şekil 4'te Ö22, Ö23, Ö24 ve Ö25 kodlu öğrencilerin hazırladıkları hücre modeli taslağ1 verilmiştir. Verilen şekil incelendiğinde öğrencilerin bir bitki hücresi modeli oluşturmayı planladıkları görülmektedir. Hazırladıkları taslakta, modellerinde yer vermeyi düşündükleri organelleri ve hücrenin genel yapısını çizdikleri, sağ tarafta ise bu model için kullanmayı düşündükleri malzeme ve araçlara yer vermişlerdir.

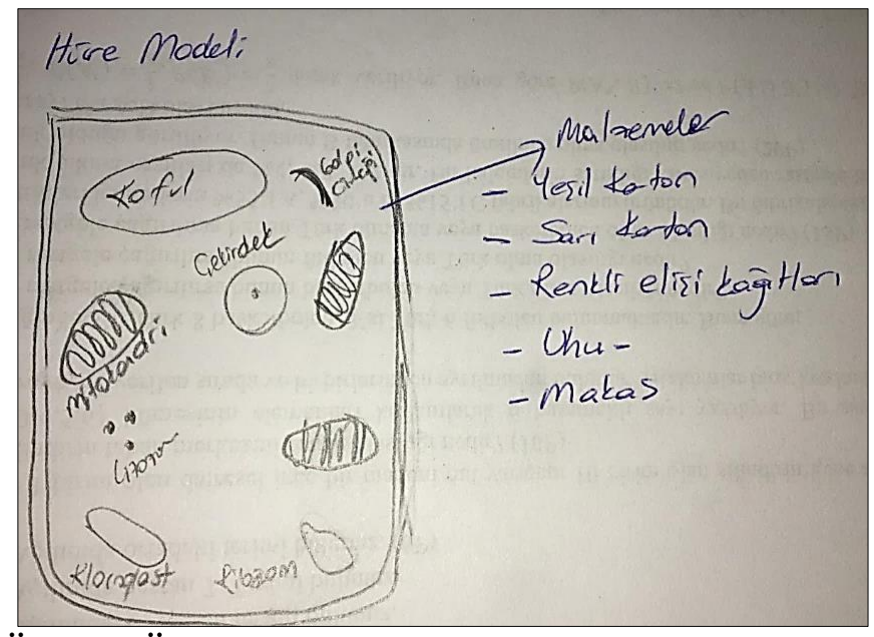

Şekil 4. Ö22, Ö23, Ö24 ve Ö25 kodlu öğrencilerin modelleri için hazırladıkları taslak

Verilen örnekler incelendikten sonra süreçsel beceriler kapsamında dördüncü beceri model planı hazırlama becerisi olarak isimlendirilmiştir. Model planı hazırlama becerisinin göstergeleri Yapacağı modelin taslağını eksiksiz ve ölçekli şekilde oluşturur. Yapacağı modelin taslağı üzerinde nerede hangi malzemelerin ve araçların kullanılacağın belirtir ve Modelleme sürecini organize eder şeklindedir.

Sonuç olarak bu araştırmada ortaokul öğrencilerinin modelleme sürecinde sahip olduğu beceriler belirlenmeye çalışılmıştır. Elde edilen bulgular ışığında öğrencilerin modelleme becerileri Şekil 5'teki gibi isimlendirilmiştir. 


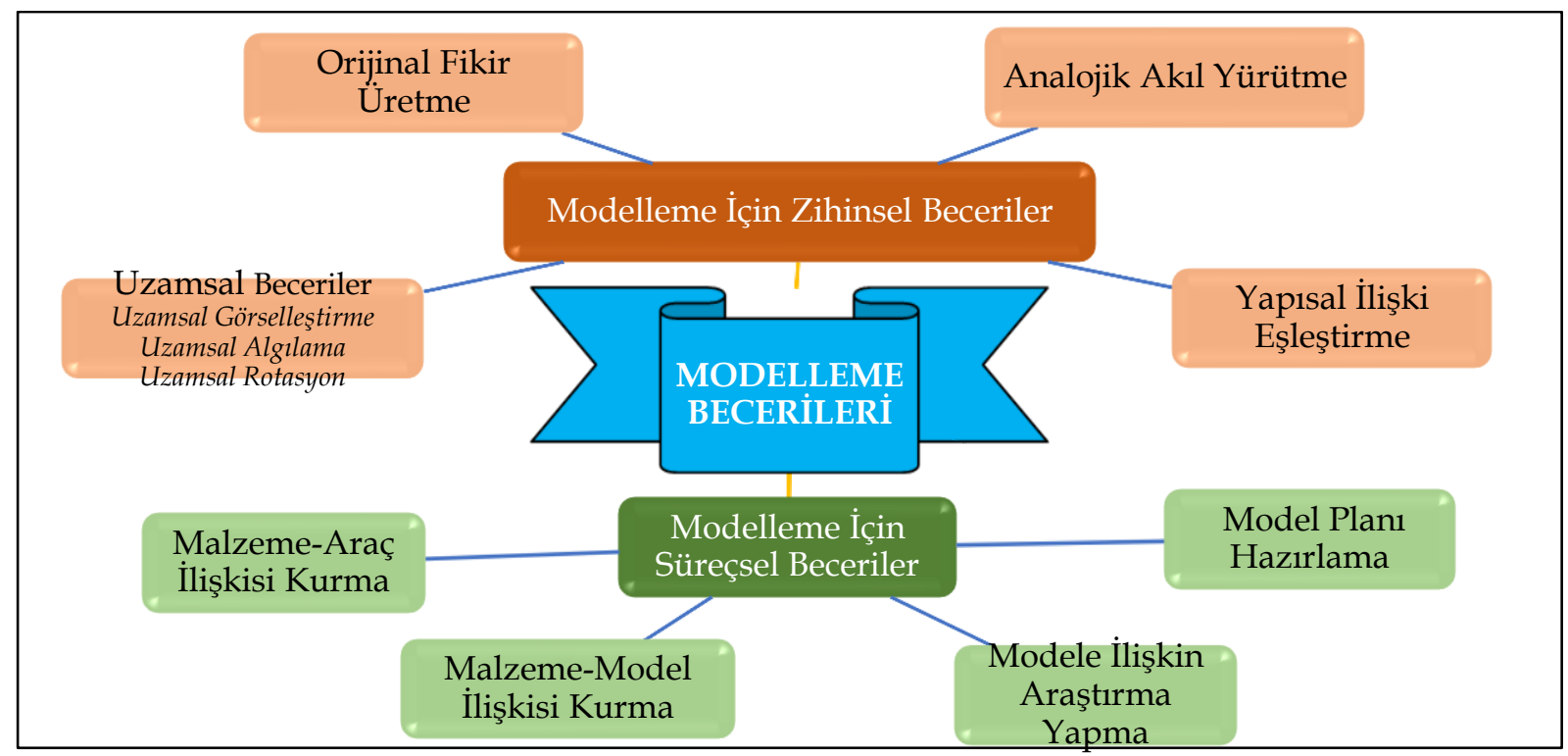

Şekil 5. Modelleme becerileri

Araştırmada Şekil 5'te de görüldüğü gibi “Modelleme için zihinsel beceriler" ve "Modelleme için süreçsel beceriler" temaları altında toplam sekiz modelleme becerisi belirlenmiştir. Modelleme için zihinsel beceriler teması altında uzamsal beceriler (uzamsal görselleştirme, uzamsal algılama, uzamsal rotasyon), orijinal fikir üretme, analojik akıl yürütme ve yapısal ilişki eşleştirme olmak üzere toplam dört beceri yer almaktadır. Modelleme için süreçsel beceriler teması altında ise malzemearaç ilişkisi kurma, malzeme-model ilişkisi kurma, modele ilişkin araştırma yapma ve model planı hazırlama olmak üzere toplam dört beceri yer almaktadır.

\section{Tartışma, Sonuç ve Öneriler}

Ortaokul öğrencilerinin modelleme sürecinde ihtiyaç duydukları becerilerin belirlenmesi amacıyla gerçekleştirilen bu araştırmada altı zihinsel beceri ve dört süreçsel beceri belirlenmiştir. Araştırmacılar, öğrencilerin yaptığ1 modelleri, modelleme sürecindeki davranışlarını, kendi notlarını ve literatür taramasını da kullanarak zihinsel beceriler başlığı altında yer alan birinci beceriyi uzamsal beceri olarak adlandırmıştır. Çünkü öğrencilerin modelleme sürecinin başında yer alan taslak oluşturma sürecinde, gözlemlerinden ve deneyimlerinden hareketle bir model çizimi yapmaya çalıştıkları görülmüştür. Gözlenen davranış uzamsal beceriler başlığı altında uzamsal görselleştirme becerisi olarak isimlendirilmiştir. Yani uzamsal görselleştirme becerisi “iki boyutlu çizimleri üç boyutlu nesnelere dönüştürür" ve "üç boyutlu nesneleri iki boyutlu çizimlere indirger" göstergeleri olarak isimlendirilmiştir. İlgili literatürde de bu çalışmadakine benzer ve farklı sınıflandırmalara rastlanmaktadır (French, 1951'den akt., Carroll 1993; Kimura, 1999; Linn ve Petersen, 1985; Yıldız, 2009; Yolcu, 2008). Linn ve Petersen (1985), uzamsal becerileri uzamsal görselleştirme, uzamsal algılama ve zihinsel çevirme olmak üzere üç kategoride incelemiştir. Benzer şekilde Kimura (1999) ise yaptığı deneysel çalışmalardan yola çıkarak uzamsal beceriyi altı boyutta sınıflandırmıştır. Bu sınıflandırma; uzamsal yönelim, uzamsal yer belleği, hedefleme, uzamsal görselleştirme, nesneleri ayırt etme ve uzamsal alg1 becerileri şeklindedir. Kimura (1999) tarafından yapılan bu sınıflandırmada uzamsal görselleştirme becerisi, nesnenin dinamik ile statik 
görünümleri arasındaki ilişkiyi tahmin edebilmesi olarak tanımlanmıştır. Bunun yanında Kimura (1999) uzamsal görselleştirme becerisini, üç boyutlu bir objenin iki boyutlu halini canlandırabilmek olarak ifade etmiştir. Kimura (1999) tarafından ifade edilen uzamsal görselleştirme becerisi, bu araştırmadaki uygulamalar sonucunda tespit edilen uzamsal becerilerden uzamsal görselleştirme becerisinin davranış kodlarını destekler niteliktedir.

Araştırmacılar, bazı öğrencilerin farklı modeller yaptığını ve yapılan bu modellerin cisim etrafında hareket ederek gözlemlemede zorluk çektiklerini gözlemlemiştir. İlgili literatür (Kimura, 1996; Linn ve Petersen, 1985) öğrenci gruplarının bu davranışlarını ve mülakat ile alan notlarını da göz önünde bulundurarak, modelleme yaparken gözlenen bu davranış, uzamsal algılama olarak isimlendirilmiştir. Buradaki uzamsal algılamanın anlamı sabit nesne etrafindaki hareketi sonucu meydana gelen geometrik değişimler arasında ilişki kurar şeklindedir. Kimura (1996) uzamsal algılamayı, farklı modellerde yatay ve dikey yönleri belirleyebilme becerisi olarak tanımlamaktadır. Linn ve Petersen (1985) ise uzamsal algılama becerisini, kişinin kendi bedeninin hareketine göre etrafındaki nesneler ile uzamsal ilişkiler kurabilmesi şeklinde ifade etmiştir. Aslında Linn ve Petersen (1985) ile Kimura (1996) tarafından uzamsal algıya yönelik yapılan bu tanımların ortak yönünün nesnelere farklı bakış açısı ile bakarak, özellikleri arasında bir ilişki kurulmasıdır. Uzamsal algılama becerisinde de nesne etrafında gözlem gerçekleştiren bireylerin, bu gözlemleri neticesinde belirlediği değişkenler arasındaki ilişkileri kurması gerekmektedir.

Araştırmada gözlenen bazı davranışlara bakıldığında, yapılan model taslakları ve modeller için yaratıcılığın ön planda olduğu görülmektedir. Örneğin; Ö5, Ö6, Ö7 ve Ö8 kodlu öğrencilerin modellerini oluştururken aslında, taslak üzerinde yer alan çizimin birebir kopyasını oluşturmaktansa öğrendikleri kavramlarla birlikte modellerini yorumlayarak oluşturmaya çalıştıkları belirlenmiştir. Yani öğrenciler hem inceleme yaptıkları modelleri hem elde ettikleri ve oluşturdukları taslakları hem de getirdikleri malzemeleri kendi düşünsel süreçlerinden geçirerek bir model yorumu oluşturmuşlar, bu sayede özgün bir model oluşturmaya çalışmışlardır. Yaratıcılığın ön planda olduğu bu beceri orijinallik olarak isimlendirilmiştir. İlgili literatürde (Arslan ve Doğru, 2014) daha çok yaratıcılık becerisi olarak ifade edilen bu kavramın özünü; merak, üretme kapasitesi, cesaret, yenilik, farklılık, kalıpları yıkma, özgünlük, çok yönlülük, esneklik gibi kavramlar oluşturmaktadır (Sayan ve Hamurcu, 2018). Sayan ve Hamurcu (2018) tarafından ifade edilen bu özellikler, bu araştırmada yaratıcılık bağlamında gözlemlenen davranışları destekler niteliktedir. Bu araştırmadaki orijinal fikir üretme becerisi incelendiğinde, söz konusu becerinin aslında yaratıcı düşünme sürecinin iç içe olduğu görülebilir. Arslan ve Doğru (2014), modellemeye dayalı fen öğretiminin ilköğretim öğrencilerinin anlama, hatırda tutma, yaratıcılık düzeyleri ile zihinsel modelleri üzerine etkisi isimli bir çalışma yürütmüştür. Bu çalışmasında Arslan ve Doğru (2014) öğrencilerin yaratıcılık düzeyleri ile modellemeye dayalı öğretim yöntemi arasında olumlu bir ilişki bulmuştur. Arslan ve Doğru'nun (2014) elde ettiği bu sonuç, bu araştırmada yer alan orijinal fikir üretme becerisinin de modelleme süreci ile ilgili olduğunun bir göstergesi olarak düşünülebilir. Çünkü modelleme sürecinde öğrencilerden beklenen, oluşturulacak modelin kendi zihinsel üretimlerinin bir sonucu olan bir ürün olmasıdır. 
Araştırma kapsamında belirlenen analojik akıl yürütme göstergeleri, yapılandırmacı kuram çerçevesinde değerlendirildiğinde öğrencilerin model oluşturma sürecinde yapılandırmacı bir süreç içerisinde davranış sergilemelerine katkı sağladığı ifade edilebilir. Bununla birlikte analojik akıl yürütme becerisi ilgili literatürde (Higgins, 1994; Mauzy ve Harrimann, 2003), birbirine benzemeyen ancak analoji yoluyla bazı benzerliklere sahip olduğu ortaya konulan iki şey arasındaki karşılaştırma olarak ifade edilmektedir. Yani analojide bir problemi çözmek için biri problemden biri de bağlantısız bir alandan oluşan ve bağlantılı olmayan iki şeye bakılır. Bu çalışmada yer alan benzerlik, öğrencilerin geçmişteki yaşantıları ve gelecekteki uyarlamaları ile şu an oluşturdukları modeller arasındadır. Yani literatürde geçen analojik akıl yürütme becerisi bu araştırmadaki geçen davranışlarla örtüşmektedir (Higgins, 1994; Mauzy ve Harriman, 2003; Michalko, 2006; Özdemir, 2017).

Öğrencilerin modelleme sürecinde gerçekleştirdiği davranışlar incelendiğinde, modelini yapacakları kaynak nesnenin (sistemin) davranışına ilişkin bir zihinsel çıkarım yapmaya çalıştıkları görülmektedir. İlk olarak, kaynak nesnede belirledikleri yapı ile bu yapıya benzettikleri model parçasını belirlemiş, daha sonra bunlar arasında kuracağı ilişkiyi ifade etmeye çalışmışlardır. Bu noktada öğrencilerin modellerinde kurdukları ilişkileri de gerekçelendirmeye çalıştıkları görülmektedir. Gerekçenin olmadığı bir ilişki yapısının, istenilen şekilde doğru kurulamayacağı düşünüldüğünde, öğrencilerin zihinsel süreçlerinde bu davranışları gerçekleştirmeleri beklenen bir durumdur. Özdemir (2017) yapısal ilişki eşleştirmesini, birbirine benzemeyen sistemler arasındaki ilişkileri benzer işlemler kullanarak açıklama olarak ifade etmiştir. Aslında Özdemir'in (2017) burada ifade ettiği şey, Gentner ve Gentner (1983) tarafından da belirtildiği gibi, öğretilmek istenen hedef kavramdan yola çıarak bir model oluşturmadır ve bu model oluşturma sürecine de yapısal ilişki eşleştirmesi denir. Bu araştırmada da öğrencilerde gözlenen "oluşturulan model ile bu modelin oluşturulduğu obje arasında bir ilişki kurabileceği özellikleri tespit etme ve model ile bu modelin oluşturulduğu obje arasında, sistemsel ilişki kurma" davranışları ilgili literatürdeki yapısal eşleştirme becerisi kavramını destekler niteliktedir.

Süreçsel beceriler kapsamında değerlendirildiğinde, öğrencilerin genel olarak malzeme ile araç arasındaki ilişkiyi ve farkı kavramada zorluk çektikleri gözlenmiştir. Yani öğrencilerin belirlediği malzeme için hangi aracı kullanması gerektiğini de tam olarak bilememiştir. Ayvacı, Bebek, Atik, Keleş ve Özdemir (2016) tarafından yürütülen çalışmada, öğrencilerin modelleme yaparken hangi malzemeleri seçeceği konusunda, görüntüsü güzel ve ilginç olan malzemelerin tercih edilmesi sonucuna ulaşılmıştır. Ayvacı ve diğerleri (2016) tarafından elde edilen bu sonuç, öğrencilerin malzeme seçiminde zorluk yaşamaları bağlamında yürütülen araştırma ile benzerlik göstermektedir. Bu duruma ek olarak öğrenciler seçtiği malzemelerin, her yerden bulunabilmesine ve ekonomik olmasına dikkat etmiştir. Model oluşturma sürecinin önemli özelliklerinden birinin de seçilen modellerin ekonomik olması gerekliliği düşünüldüğünde, öğrencilerin bu beceriye sahip olmasının da önemi oldukça büyüktür (Svoboda ve Passmore, 2013; Van Driel ve Verloop, 1999). Sonuç olarak bu araştırmada öğrencilerin modelleme sürecinde yukarıda sayılan göstergeler, malzeme-model ilişkisi kurma becerisi olarak adlandırılmıştır. 
Öğrenciler modele yönelik araştırmalarını uygulamaya gelmeden önce evlerinde ya da okulda bir araya gelerek, genelde bir ya da iki kaynakla yapmışlardır. $\mathrm{Bu}$ bağlamda öğrencilerin modelleme sürecine yönelik gözlemlenen davranışları "Model için gerçekleştireceği araştırmanın sürecini bilme, araştırma kapsamında kitaplar, ilgili literatür tarama, videolar izleme gibi hangi kaynaklardan yararlanacağını bilme ve model için topladığı dokümanları değerlendirerek sonuç çıkarma" şeklindedir. Bu gözlenen davranışlara ait modelleme becerisine araştırma sonucunda modele ilişkin araştırma yapma becerisi adı verilmiştir. Bu araştırmada, öğrenciler modellerine yönelik tercih ettikleri kaynaklar, internet, kitaplar, aile bireylerine sorma ve ilgili videolar izleme şeklindedir. Ayrıca modelleme sürecinin ilk aşamasında model ile ilgili veriler toplanmıştır (Barnea ve Dori, 2000; Maia ve Justi, 2009; Mendonça ve Justi, 2011; Schauble, Glaser, Raghavan ve Reiner, 1991; Schwarz ve White, 2005). Dolayısıyla modele ilişkin araştırma yapma becerisinin model oluşturma sürecinde yeri ve önemi oldukça büyüktür.

Fen öğretiminde yer alan kazanımları öğrencilere kazandırabilmenin en etkili yöntemlerinden biri de modellemeye dayalı öğretim yöntemleridir. Çünkü fenin doğası gereği öğrencilere verilmesi istenen kazanımlar deney ve gözlem sonucunda daha kalıcı hale gelebilir. Bu süreçte de öğrencileri en aktif kılan yöntemlerden biri, modellemeye dayalı öğrenme olarak karşımıza çıkmaktadır. Modellemeye dayalı öğrenmenin gerçekleşebilmesi için de bu araştırmada yer alan modelleme becerilerinin hem öğrencilere hem de öğretmenlere kazandırılması gerekir. Söz konusu becerileri kazanan bireyler, modelleme etkinliklerini derslerinde kolaylıkla kullanabileceklerdir. Bununla birlikte, araştırma kapsamında belirlenen bu becerilerin nasıl geliştirileceği de önemlidir. Bu becerilerin geliştirilmesine yönelik etkinliklerin ya da öğrenme ortamlarının tasarlanması ve bunların araştırma sonucunda belirlenen becerilere olası etkilerinin incelenmesi ilerde yapılacak araştırmalara konu olabilir. Diğer yandan gelecekte yapılacak çalışmalarla, bu araştırmada yer alan ortaokul öğrencileri yerine, daha düşük sınıf düzeyleri ile orta öğretim öğrencileri ve yüksek öğretimde öğrenim gören öğretmen adaylarının, benzer bir araştırma tasarımıyla sahip oldukları modelleme becerilerinin tespit edilmesi, bu sayede modelleme becerilerinin bilişsel düzeylere göre muhtemel bir sınıflandırılmasının gerçekleştirilmesi önerilmektedir. Bu bağlamda, araştırma kapsamında belirlenen zihinsel ve süreçsel becerilerin farklı bilişsel seviyedeki bireylerdeki varlığı tespit edilebilir.

\section{Kaynakça}

Aktan, M. B. (2005). Investigation of prospective teachers' knowledge and understanding of models and modeling and their attitudes towards the use of models in science education (Unpublished doctoral dissertation). Purdue University, Indiana, USA.

Araya, R., Jiménez, A., Bahamondez, M., Calfucura, P., Dartnell, P. and SotoAndrade, J. (2012). Teaching modeling skills using a massively multiplayer online mathematics game. World Wide Web, 17(2), 213-227. https://doi.org/10.1007/s11280-012-0173-5.

Arslan, A. (2013). Modellemeye dayal fen öğretiminin ilköğretim öğrencilerinin anlama, hatırda tutma, yaratıcilı düzeyleri ile zihinsel modelleri üzerine etkisi 
(Yayımlanmamış yüksek lisans tezi). Akdeniz Üniversitesi, Eğitim Bilimleri Enstitüsü, Antalya.

Arslan, A. ve Doğru, M. (2014). Modellemeye dayalı fen öğretiminin ilköğretim öğrencilerinin anlama, hatırda tutma, yaratıcılık düzeyleri ile zihinsel modelleri üzerine etkisi. Mediterranean Journal of Humanities, 4(2),1-17. https:/ / doi.org/10.13114/MJH.201428425.

Ayvacı, H. Ş. ve Bakırcı, H. (2012). Fen ve teknoloji öğretmenlerinin fen öğretim süreçleriyle ilgili görüşlerinin 5E modeli açısından incelenmesi. Türk Fen Ĕ̈itimi Dergisi, 9(2), 132-151.

Ayvacı, H. Ş. ve Y1lmaz, B. C. (2009). Investigating the effect of drama activity called 'mirrors and their usage' to student succession developed according to elaborating stage of 5E model. Procedia Social and Behavioral Sciences, 1(1), 2712-2717. https:// doi.org/10.1016/j.sbspro.2009.01.480.

Ayvacı, H. Ş., Bebek, G., Atik, A., Keleş, C. B. ve Özdemir, N. (2016). Öğrencilerin sahip oldukları zihinsel modellerin modelleme süreci içerisinde incelenmesi: Hücre konusu örneği. Ziya Gökalp Eğitim Fakültesi Dergisi, 28, 175-188. https://doi.org/10.14582/DUZGEF.711.

Bamberger, Y. M. and Davis, E. A. (2013). Middle-school science students' scientific modelling performances across content areas and within a learning progression. International Journal of Science Education, 35(2), 213-238. https://doi.org/10.1080/09500693.2011.624133.

Barnea, N. and Dori, Y. J. (2000). Computerized molecular modeling: The new technology for enhance model perception among chemistry educators and learners. Chemistry Education: Research and Practice in Europe, 1, 109-120. https:/ / doi.org/10.1039/ A9RP90011J.

Batı, K. (2014). Modellemeye dayal fen eğitiminin etkililiğ doğası görüşleri ile eleştirel düşünme becerilerini etkisi (Yayımlanmamış doktora tezi). Hacettepe Üniversitesi, Eğitim Bilimleri Enstitüsü, Ankara.

Bilgin, İ. ve Geban, Ö. (2001). Benzetim (analoji) yöntemi kullanarak lise 2. sınıf öğrencilerinin kimyasal denge konusundaki kavram yanılgılarının giderilmesi. Hacettepe Üniversitesi Eğitim Fakültesi Dergisi, 20, 26-32.

Borges, A. T. and Gilbert, J. K. (1999). Mental models of electricity. International Journal of Science Education, 21(1), 95-117. https://doi.org/10.1080/095006999290859.

Campbell, T., Zhang, D. and Neilson, D. (2011). Model based inquiry in the high school physics classroom: An exploratory study of implementation and outcomes. Journal of Science Education and Technology, 20, 258-269. https:/ / doi.org/10.1007/s10956-010-9251-6.

Carroll, J. B. (1993). Human cognitive abilities: A survey of factor-analytic studies. New York: Cambridge University Press. https://doi.org/10.1017/CBO9780511571312.

Çepni, S. ve Çil, E. (2009). Fen ve teknoloji programı. ilköğretim 1. ve 2. kademe öğretmen el kitabi. Ankara: Pegem Akademi.

Cheng, M., Wu, T. and Lin, S. (2019). Investigating the relationship between views of scientific models and modeling practice. Research in Science Education, 1-17. https://doi.org/10.1007/s11165-019-09880-2. 
Coll, R. K. and Treagust D. F. (2003). Learners mental models of metallic bonding: A cross-age study. Science Education, 87, 685-707. https://doi.org/10.1002/sce.10059.

Davey, L. (1991). The application of case study evaluations. Practical Assessment Research and Evaluation, 2(9), 1-2.

https:/ / pareonline.net/getvn.asp?v=2\&n=9 adresinden 14 Temmuz 2018 tarihinde edinilmiştir.

Demir, A. and Namdar, B. (2019). The effect of modeling activities on grade 5 students' informal reasoning about a real-life issue. Research in Science Education, https://doi.org/10.1007/s11165-019-09896-8.

Demirçalı, S. (2016). Modellemeye dayal fen öğretiminin öğrencilerin akademik başarlarına, bilimsel süreç becerilerine ve zihinsel model gelişimlerine etkisi: 7. sinıf güneş sistemi ve ötesi-uzay bilmecesi ünitesi örneği (Yayımlanmamış yüksek lisans tezi). Gazi Üniversitesi, Eğitim Bilimleri Enstitüsü, Ankara.

Doruk, B. K. (2010). Matematiŏi günlük yaşama transfer etmede matematiksel modellemenin etkisi (Yayımlanmamış doktora tezi). Hacettepe Üniversitesi, Sosyal Bilimler Enstitüsü, Ankara.

Düşkün, İ. (2011). Güneş-dünya-ay modeli geliştirilmesi ve fen bilgisi öğretmen adaylarının astronomi eğitimindeki akademik başarılarına etkisi (Yayımlanmamış yüksek lisans tezi). İnönü Üniversitesi, Eğitim Bilimleri Enstitüsü, Malatya.

Erduran, S. (1999). Merging curriculum design with chemical epistemology: A case of learning chemistry through modeling (Unpublished doctoral dissertation). Vadnerbilt University, Nashville, Tennessee, USA.

Ergün, A. and Sarıkaya, M. (2019). The effect of model based learning on the academic success and conceptual understanding of middle-school students on the subject of the particulate nature of matter. Electronic Journal of Social Sciences, 18(72), 1960-1976. https:/ / doi.org/10.17755/esosder.539584.

Fisher, R. (2005). Teaching children to learn (2nd ed.). Cheltenham: Nelson Thornes. Gentner, D. and Gentner, D. R. (1983). Flowing waters or teeming crowds: Mental models of electricity. In D. Gentner and A. L. Stevens (Eds.), Mental models (pp. 99-129). Hillsdale, New Jersey, NJ: Lawrence Erlbaum Associates.

Gözmen, E. (2008). Lise 1. sinıf biyoloji dersinde okutulan "mayoz bölünme" konusunun ögretilmesinde modellerin ögrrenmeye etkisi (Yayımlanmamış yüksek lisans tezi). Selçuk Üniversitesi, Fen Bilimleri Enstitüsü, Konya.

Güneş, B., Bağc1, N. ve Gülçiçek, Ç. (2004). Fen bilimlerinde kullanılan modellerle ilgili öğretmen görüşlerinin tespit edilmesi. Abant İzet Baysal Üniversitesi Ĕ̈itim Fakültesi Dergisi, 4, 1-14.

Harrison, A. G. and Treagust, D. F. (2000). A typology of school science models. International Journal of Science Education, 22, 1011-1026. https:/ / doi.org/10.1080/095006900416884.

Higgins, J. M. (1994). 101 Creative problem solving techniques: the handbook of new ideas for business. New York, NY: New Management Publishing.

Huguet, M. J., Erschler, J., De Terssac, G. and Lompré, N. (1996). Negotiation based on constraints in cooperation. Computer Supported Cooperative Work (CSCW), 5(2), 267-284. https:/ / doi.org/10.1007/BF00133659. 
İnal, Z. ve Aydın, A. (2015). Madde ve 1sı ünitesinin öğretilmesinde model kullanımının akademik başarıya ve bilgilerin kalıcılığına etkisi. Ahi Evran Üniversitesi Kırşehir Eğitim Fakültesi Dergisi, 16(3), 19-37.

Ingham, A. M. and Gilbert, J. K. (1991). The use of analogue models by students of chemistry at higher education level. International Journal of Science Education, 22(9), 1011-1026. https:/ / doi.org/10.1080/0950069910130206.

Kimura, D. (1996). Sex, sexual orientation and sex hormones influence human cognitive function. Current Opinion in Neurobiology, 6, 259-263. https:/ / doi.org/10.1016/S0959-4388(96)80081-X.

Kimura, D. (1999). Sex and cognition. Cambridge: MIT Press. https://doi.org/10.7551/mitpress/6194.001.0001.

Lesh, R. A. and Doerr, H. (2003). Foundations of model and modelling perspectives on mathematic teaching and learning. In R. A. Lesh and H. Doerr (Eds.), Beyond constructivism: A models and modelling perspectives on mathematics teaching, learning and problem solving (pp. 3-33). Mahwah, NJ: Lawrance Erlbauum. https:/ / doi.org/10.4324/9781410607713.

Linn, M. C. and Petersen, A. C. (1985). Emergence and characterization of sex differences in spatial ability: A meta-analysis. Child Development, 56, 14791498. https:/ / doi.org/10.2307/1130467.

Lohman, D. F. (1993). Spatial ability and G. Paper presented at the First Spearman Seminar, University of Plymouth, Iowa. Retrieved May 25, 2018, from http:/ / faculty.education.uiowa.edu/dlohman.

Maaß, K. (2007). Modelling in class: What do we want the students to learn? In mathematical modeling. In C. Haines, P. Galbraith, W. Blum and S. Khan. Mathematical Modelling, (pp. 63-78). Cambridge: Woodhead Publishing. https://doi.org/10.1533/9780857099419.2.63.

Maia, P. F. and Justi, R. (2009). Learning of chemical equilibrium through modellingbased teaching. International Journal of Science Education, 31(5), 603-630. https:// doi.org/10.1080/09500690802538045.

Marshall C. and Rossman, G. B. (2006). Designing qualitative research. Thousands Oaks: Sage Publication.

Mauzy, J. and Harriman, R. A. (2003). Three climates for creativity. ResearchTechnology Management, 46(3), 27-30. https://doi.org/10.1080/08956308.2003.11671563.

Mendonça, P. C. C. and Justi, R. (2011). Contributions of the 'Model of Modelling' diagram to the learning of ionic bonding: Analysis of a case study. Research in Science Education, 41(4), 479-503. https:/ / doi.org/10.1007/s11165-0109176-3.

Merriam, S. B. (2013). Nitel araştırma desen ve uygulama için bir rehber (S. Turan, Çev.) Ankara: Nobel Yayın Dağıtım.

Michalko, M. (2006). Thinkertoys: A handbook of creative thinking techniques. Berkeley, California, CA: 10 Speed Press.

Ogan-Bekiroğlu, F. (2007). Effects of model-based teaching on pre-service physics teachers' conceptions of the moon, moon phases, and other lunar phenomena. International Journal of Science Education, 29(5), 555-593. https://doi.org/10.1080/09500690600718104. 
Özdemir, A. A. (2017). Eğitim fakültelerindeki fen bilgisi öğretmen adaylarının model ve modelleme hakkındaki düşüncelerinin analizi (Yayımlanmamış yüksek lisans tezi). Kahramanmaraş Sütçü İmam Üniversitesi, Fen Bilimleri Enstitüsü, Kahramanmaraş.

Sayan, Y. ve Hamurcu, H. (2018). İlköğretim fen ve teknoloji dersi için geliştirilen materyallerin öğrencilerin yaratıcı düşünme becerilerine ve öz kavramlarına etkileri. Education Sciences, 13(2), 106-120. http:/ / dx.doi.org/10.12739/NWSA.2018.13.2.1C0683.

Schauble, L., Glaser, R., Raghavan, K. and Reiner, M. (1991). Casual models and experimentation strategies in scientific reasoning. The Journal of the Learning Sciences, 1, 201-238. https://doi.org/10.1207/s15327809jls0102_3.

Schwarz, C. V. and White, B. Y. (2005). Metamodeling knowledge: Developing students understanding of scientific modeling. Cognition and Instruction, 23, 165-205. https:/ / doi.org/10.1207/s1532690xci2302_1.

Schwarz, C. V., Reiser, B. J., Davis, E. A., Kenyon, L., Achér, A., Fortus, D., ... Krajcik, J. (2009). Developing a learning progression for scientific modeling: Making scientific modeling accessible and meaningful for learners. Journal of Research in Science Teaching, 46(6), 632-654. https://doi.org/10.1002/tea.20311.

Sins, P. H., Savelsbergh, E. R. and Van Joolingen, W. R. (2005). The difficult process of scientific modelling: An analysis of novices' reasoning during computerbased modelling. International Journal of Science Education, 27(14), 1695-1721. https:// doi.org/10.1080/09500690500206408.

Soylu, H. (2004). Fen öğretiminde yeni yaklaşımlar: Keşif yoluyla öğrenme. İstanbul: Nobel Yayımcilik.

Svoboda, J. and Passmore, C. (2013). The strategies of modeling in biology education. Science and Education Journal, 22, 119-142. https:/ / doi.org/10.1007/s11191011-9425-5.

Taylor, I., Barker, M. and Jones, A. (2003). Promoting mental model building astronomy education. International Journal of Science Education, 25(10), $1205-$ 1225. https:// doi.org/10.1080/0950069022000017270a.

Ünal-Çoban, G. (2009). Modellemeye dayal fen öğretiminin öğrencilerin kavramsal anlama düzeylerine, bilimsel süreç becerilerine, bilimsel bilgi ve varlık anlayışlarına etkisi: 7. Sınıf ışık ünitesi örneği (Yayımlanmamış doktora tezi). Dokuz Eylül Üniversitesi, Eğitim Bilimleri Enstitüsü, İzmir.

Van Driel J. H. and Verloop N. (1999). Teachers' knowledge of models and modelling in science. International Journal of Science Education, 21(11), 1141-1153. https:// doi.org/10.1080/095006999290110.

Vosniadou S. (2002). Mental models in conceptual development. In L. Magnani and N. J. Nersessian (Eds.) Model-based reasoning (pp. 353-368). Boston, MA: Springer. https://doi.org/10.1007/978-1-4615-0605-8_20.

Wells, M., Hestenes, D. and Swackhamer, G. (1995). A modeling method for high school physics instruction. American Journal of Physics, 63, 606-619. https://doi.org/10.1119/1.17849.

Wilson, J. and Wing Jan, L. (1993). Thinking for themselves. Malvern, Victoria: Eleanor Curtain Publishing. 
Yıldız, B. (2009). Üç boyutlu ortam ve somut materyal kullanımının uzamsal görselleştirme ve zihinde döndürme becerilerine etkileri (Yayımlanmamış yüksek lisans tezi). Hacettepe Üniversitesi, Fen Bilimleri Enstitüsü, Ankara.

Yin R. K. (2009). Case study research: Design and methods (4th ed.). California: SAGE Pub. Thousand Oaks.

Yolcu, B. (2008). Altıncı sını öğrencilerinin uzamsal yeteneklerinin somut modeller ve bilgisayar uygulamaları ile geliştirme çalışmaları (Yayımlanmamış yüksek lisans tezi). Eskişehir Osmangazi Üniversitesi, Fen Bilimleri Enstitüsü, Eskişehir.

Zeynelgiller, O. (2006). İlköğretim II. kademe fen bilgisi dersi kimya konularnda model kullanımının öğrenci başarısına etkisi (Yayımlanmamış yüksek lisans tezi). Celal Bayar Üniversitesi, Fen Bilimleri Enstitüsü, Manisa.

\section{Summary}

\section{Introduction}

In order to make the abstract and complex concepts within the content of science courses concretely visible and tangible, many teaching activities that can stimulate the visual and intellectual structures of the students are included. One of these teaching activities is model building and using activities. Such activities have long been used in teaching activities of students (Van Driel and Verloop, 2002). In science, modeling is defined as the whole process made to make an unknown target understandable from the existing concepts, while the product resulting from modeling is described as a model (Harrison, 2001; Treagust, Chittleborough and Mamiala, 2002). Modelling; since it involves presenting ideas, objects or events in mental, physical or verbal ways, it enables students to explain their scientific phenomena and develop their conceptual understanding by creating their own models (Treagust, Chittleborough and Mamiala, 2002). In this context, modeling activities have great importance in terms of achieving the objectives of science which is a conceptual and procedural course.

Similar to the modeling process in science, they need some skills that we call scientific process skills in order to increase the permanence of learning, to facilitate learning, to enable students to take responsibility in their own learning and to provide students with research methods and methods (Çepni and Çil, 2009; Ayvacı and Y1lmaz, 2009; Ayvac1 and Bakırc1, 2012). In this process, students are expected to develop basic skills such as observing, measuring, recording data and establishing number and space relationships, as well as experimental skills such as hypothesizing, controlling variables by identifying and experimenting. For these skills to occur in students, some technical skills such as recognizing and using the tools in the experiment must be acquired before the experiment. A similar situation exists before modeling activities as well as experimental activities. So; scientific process skills are expected to be developed for a student to conduct experiments; modeling skills are expected to be improved before the model building process.

In the process of model building, it is necessary to know the difficulties that students will face while making a modeling study and what thinking processes, they apply; it is emphasized that the modeling process is more important than the stages. Moreover, the modeling stages vary according to the types of modeling and are evaluated under different subtitles. In these evaluations, it is seen that the main 
categories such as planning, analyzing, determining the model, reasoning, interpretation, synthesis, evaluation and critical and the sub-categories related to these main categories come to the fore. A limited number of studies have been conducted on what skills or skills are required to carry out these stages. Therefore, the aim of this study is to determine the skills that secondary school students need in the modeling process.

\section{Method}

This study, which aims to determine modeling skills, was carried out in qualitative design by its nature. In the study where the case study was determined as a method, the data were collected in two periods as pilot and main study. The pilot study period was carried out in the spring semester of the 2014-2015 academic year and consisted of 10 weeks, each consisting of two modeling studies lasting five weeks. 67 students, 27 fifth graders, 22 sixth graders and 18 seventh graders, took the elective Science Applications course. In this process, unstructured observations were made, interview questions were developed, and researcher field notes were included. The main study was carried out with the modeling process which was reduced to three weeks with 57 students (17 fifth grade, 22 sixth grade and 18 seventh grade) who took elective Science Applications course at the same school in 2015-2016 fall semester. Modeling skills were determined by the help of interview questions and researcher field notes were developed in the main study.

\section{Results}

Within the scope of the study, a total of eight modeling skills were identified under the themes of mental skills for modeling and process skills for modeling. Under the theme of mental skills for modeling; spatial skills (spatial visualization, spatial perception, spatial rotation), producing an original idea, analogical reasoning and matching structural relationship. In the ability to produce an original idea, it is expected that the model will be original. This skill is an indicator that the model which the student will develop will make a mental production by separating from the other models. Spatial skills (visualization, perception, and rotation) allow the student to correctly relate and translate two-dimensional and three-dimensional objects. According to analogical reasoning, the individual needs to establish a simulated relationship with the new situation. Matching structural relationship skills, in order to describe the relationships between dissimilar systems, they should be explained by examining the situations in which they show a structural partnership.

Under the theme of procedural skills for modeling, four skills were identified: building material-tool relationship, building material-model relationship, research on modeling and preparing a model plan. Preparing a model plan is to draw the path to be followed in the process of creating the model. In research on modeling, it is expected from the individuals to collect data on the model to be formed by following the research steps. In building material-model relationship, it is necessary to determine how appropriate the materials determined for the model to be made to the model in terms of color, size, strength, machinability, etc. Finally, building material-tool relationship; it is necessary for the individual to be able to choose the appropriate equipment for the materials to be used. 


\section{Discussion}

In this research, the skills that secondary school students need in the modeling process were determined. The spatial skills (visualization, perception, rotation) determined under the theme of mental skills for modeling aim to establish the relationships between two- and three-dimensional objects. When the literature is examined, it is seen that there are studies expressing the importance of such skills. (Linn and Petersen, 1985; Kimura, 1999). The production of an original idea skill aims to exhibit mental creativity for the individual to undergo a unique production process. Arslan and Doğru (2014) found a positive relationship between creativity and modeling-based teaching. Analogical reasoning is aimed to enable students to relate their previous experiences and new situations as indicated in the literature (Mauzy and Harrimann, 2003). In matching structural relationship skills, it is important to reveal the systematic relations between the model and the source object.

When it is evaluated within the scope of procedural skills for modeling, it is observed that students have difficulty in understanding the relationship and difference between material and tool in general. Ayvacr et al. (2016) obtained similar results in their study. In addition to this, students have paid attention to the matter that the materials they choose can be found anywhere and be economical. Since one of the important features of the modeling process is that the selected models should be economic, it is important that students have this skill (Svoboda and Passmore, 2013). Other skills identified; research on modeling and preparing a model plan. Indicator behaviors related to these skills have been found in similar studies in the literature (Barnea and Dori, 2000; Maia and Justi, 2009; Mendonça and Justi, 2011).

\section{Pedagogical Implications}

For the modeling processes to be realized within the scope of science courses and the models to be produced at the end of these processes to be effective; It is recommended that students develop modeling skills and then produce a model through the modeling process. Considering the preschool period, where modeling activities and model usage are extremely important, it is recommended to determine the level of the identified skills in preschool children and whether these children have different skills.

\section{Araştırmanın Etik Taahhüt Metni}

Yapılan bu çalışmada bilimsel, etik ve alıntı kurallarına uyulduğu; toplanan veriler üzerinde herhangi bir tahrifatın yapılmadığı, karşılaşılacak tüm etik ihlallerde "Cumhuriyet Uluslararası Eğitim Dergisi ve Editörünün" hiçbir sorumluluğunun olmadığ1, tüm sorumluluğun Sorumlu Yazara ait olduğu ve bu çalışmanın herhangi başka bir akademik yayın ortamına değerlendirme için gönderilmemiş olduğu sorumlu yazar tarafından taahhüt edilmiştir.

\section{Authors' Biodata / Yazar Bilgileri}

Hakan Şevki AYVACI, lisans öğrenimini Karadeniz Teknik Üniversitesi Fatih Eğitim Fakültesi Fizik Öğretmenliği alanında almıştır. Yüksek lisans eğitimini Karadeniz Teknik Üniversitesi Fen Bilimleri Enstitüsü Fen Bilimleri Eğitimi alanında, doktorasını ise yine aynı üniversitede Fizik Eğitimi alanında tamamlamıştır. Yazar, Trabzon Üniversitesi Fatih Eğitim Fakültesi'nde profesör olarak görevine devam etmektedir. 
Hakan Şevki Ayvac1, received his BS in Physics Education at Karadeniz Technical University Fatih Faculty of Education; MS in Science Education at Karadeniz Technical University Graduate Institute of Natural and Applied Sciences and PhD in Physics Education. The author continues to work as a professor at Trabzon University Fatih Faculty of Education.

Sinan BÜLBÜL, lisans öğrenimini Gazi Üniversitesi Gazi Eğitim Fakültesi Fen Bilgisi Öğretmenliği alanında almıştır. Yüksek lisans eğitimini Gazi Üniversitesi Eğitim Bilimleri Enstitüsü Fen Bilgisi Öğretmenliği alanında, doktorasını ise Karadeniz Teknik Üniversitesi Eğitim Bilimleri Enstitüsü Fen Bilgisi Eğitimi alanında tamamlamıştır.

Sinan Bülbül, received his BS in Science Education at Gazi University Gazi Faculty of Education; MS in Science Education at Gazi University Graduate School of Educational Sciences and PhD in Science Education at Karadeniz Technical University Graduate School of Educational Sciences. 